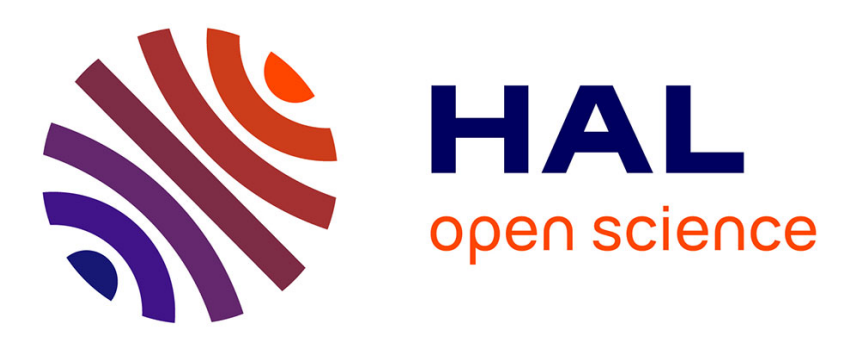

\title{
The 12 May 1802 earthquake (N Italy) in its historical and seismological context
}

\author{
Paola Albini, Andrea Rovida
}

\section{To cite this version:}

Paola Albini, Andrea Rovida. The 12 May 1802 earthquake (N Italy) in its historical and seismological context. Journal of Seismology, 2010, 14 (3), pp.629-651. 10.1007/s10950-010-9187-6 . hal-00579027

\section{HAL Id: hal-00579027 \\ https://hal.science/hal-00579027}

Submitted on 23 Mar 2011

HAL is a multi-disciplinary open access archive for the deposit and dissemination of scientific research documents, whether they are published or not. The documents may come from teaching and research institutions in France or abroad, or from public or private research centers.
L'archive ouverte pluridisciplinaire HAL, est destinée au dépôt et à la diffusion de documents scientifiques de niveau recherche, publiés ou non, émanant des établissements d'enseignement et de recherche français ou étrangers, des laboratoires publics ou privés. 


\title{
The 12 May 1802 earthquake (N Italy) in its historical and seismological context
}

\author{
Paola Albini · Andrea Rovida
}

Received: 27 May 2009 / Accepted: 16 February 2010 / Published online: 23 March 2010

(C) Springer Science+Business Media B.V. 2010

\begin{abstract}
The Mw 5.7 earthquake that occurred on 12 May 1802 is the only one with $\mathrm{Mw} \geq 5.5$ located west of Lake Garda in the centralnorthern part of the Po Plain, Northern Italy, and the strongest event located in the seismic zone 907 of the ZS9 seismogenic zonation of Italy. Current parametric earthquake catalogs locate the event not far from important cities (e.g., Milan) and to sites where nuclear power plants were to be built in the 1980 s or could be built in a near future. Although the earthquake parameters seemed sufficiently well constrained, a detailed investigation of documentary sources was performed, in repositories storing the documents of the Napoleonic departments to which the area affected by the earthquake belonged at that time. In the surviving archival series, we found the officers' correspondence on all the administrative aspects raised by the earthquake. The newly collected records allowed the authors to significantly increase the number of macroseismic intensity data, including new observations in the most damaged area. The results have been then interpreted in terms of both Mercalli-CancaniSieberg and EMS98 macroseismic scales. The
\end{abstract}

P. Albini $(\bowtie) \cdot$ A. Rovida

Sezione di Milano-Pavia,

Istituto Nazionale di Geofisica e Vulcanologia,

Via E. Bassini 15, 20133 Milan, Italy

e-mail: albini@mi.ingv.it earthquake parameters were derived applying two different methods in order to get two independent estimates. Earthquake location is confirmed, although the still scarce data available in the area to the east of the epicenter do not permit to reduce the uncertainty to a minimum. According to the Boxer method, the magnitude is now slightly higher, and the source model shows a good agreement with the tectonic setting of the area.

Keywords 1802 earthquake • Northern Italy • Historical seismology • Macroseismic intensity • Earthquake parameters

\section{Introduction}

On 12 May 1802, at 10.30 A.M., an earthquake caused serious damage in some ten places in Northern Italy, today in the provinces of Brescia, Bergamo, Lodi, and Cremona, among the most densely populated and productive of the country and just some $50 \mathrm{~km}$ away from Milan (Fig. 1). The earthquake was felt as far as Savona, Genoa, Turin, Geneva, Bern, Zürich, Chur, Rovereto, and Venice.

On 11 May 1802, around 2 P.M., a light foreshock was felt in Soncino, Orzinuovi, Bergamo (ASBg 1802c), and Cremona. Some aftershocks are described in the letters addressed to his sister by Giovanni Battista Della Volta living at 
Fig. 1 The places damaged in 1802 are shown, together with today Italian provinces, the communes classified in the second category of the 1984 seismic code, and the most recent seismic hazard assessment of Italy (MPS Working Group 2004). Shown are also the sites of the only built NPP $(c, 1978$, closed in mid 1980s) and those selected ( $t$ and $v$ ) for NPPs to be built in the 1980s

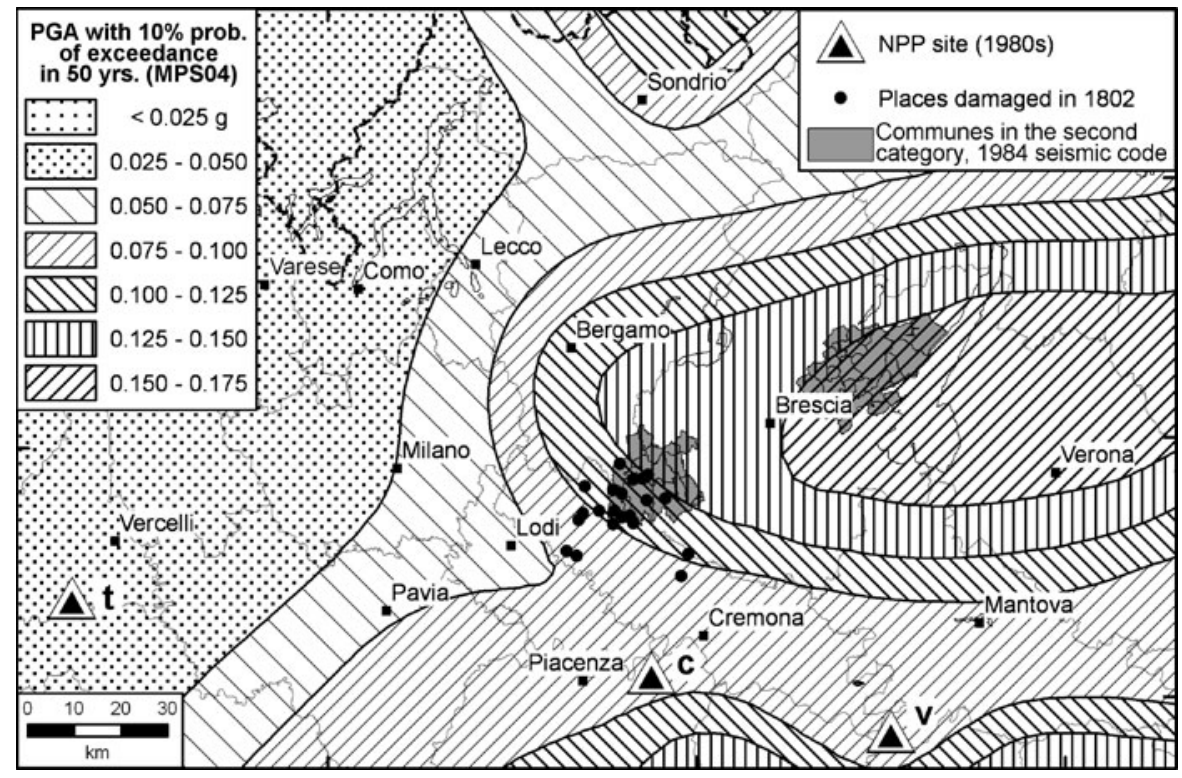

Soncino at the time of the earthquake (letters read and summarized by Galantino 1869): light ones on 13 May, then a few stronger on 14 through 20 May. A strong one reported by Della Volta is also described by a local officer (ASBg 1802l) as felt at Soncino on 2 June.

In the year 1802, the territory affected by the earthquake belonged to three departments of the Repubblica Italiana (under French control, gained by Napoleon Bonaparte in 1797): Mella (capital Brescia), Serio (Bergamo), and Alto Po (Cremona). The intervention of the government, based in Milan, was relatively fast; on 3 June 1802, the Ministry of Internal Affairs informed the prefects of the three mentioned departments that the engineer Girolamo Brioschi had been appointed to carry on damage surveys (ASBs 1802o). Some eyewitnesses wrote that there was no remembrance of such a strong earthquake in the area. Perhaps, this was the reason why Caparrotti (1802) and Balis (1802) published two leaflets with the explicit intention to leave a memory of this earthquake.

The earthquake, known to the Italian seismological tradition (Mercalli 1883, 1897; Baratta 1895-1897, 1901), was among the first events to be studied according to modern criteria in the frame of "Progetto Finalizzato Geodinamica (PFG)"; on the basis of this investigation, included in the
"Atlas of isoseismal maps of Italian earthquakes" (Brega et al. 1985), the PFG catalog (Postpischl 1985) provided an epicentral location, an Io $=8$, and a macroseismic magnitude 5.8. It was later investigated in the framework of the Catalogo dei Forti Terremoti in Italia-CFTI by Boschi et al. (1997); based on it, the Catalogo Parametrico dei Terremoti Italiani-CPTI04 (CPTI04 Working Group 2004) assessed Mw $5.67 \pm 0.09$. The subsequent versions of the CFTI (Boschi et al. 2000; Guidoboni et al. 2007) did not change the intensity distribution by Boschi et al. (1997).

This earthquake is important for a number of reasons: (a) it is responsible for the maximum ever observed intensities in more than 20 localities; (b) as a consequence, since 1984, these localities were among the few in the Po Plain inserted in the list of the communes, where buildings had to be designed according to seismic forces of the second category of the code (in 2003, the official seismic map of Italy changed dramatically); (c) the event is located not so far from important cities (Milan, Lodi, Crema, Cremona, Brescia, and Bergamo) and from sites where nuclear power plants (NPPs) were to be built in the 1980s or could be built in a near future (Fig. 1); (d) it represents a singularity in the seismicity of Northern Italy, being the only one with $\mathrm{Mw} \geq 5.5$ located west of Lake Garda in the central-northern part of the Po Plain (Fig. 2); 
Fig. 2 Historical (1000-1980, from CPTI04) and recent (1981-2002, from CSI; 2003-2008, from INGV Monthly Bulletin) seismicity and seismogenic source models according to ZS9 (Meletti et al. 2008) and DISS3 (Basili et al. 2008)

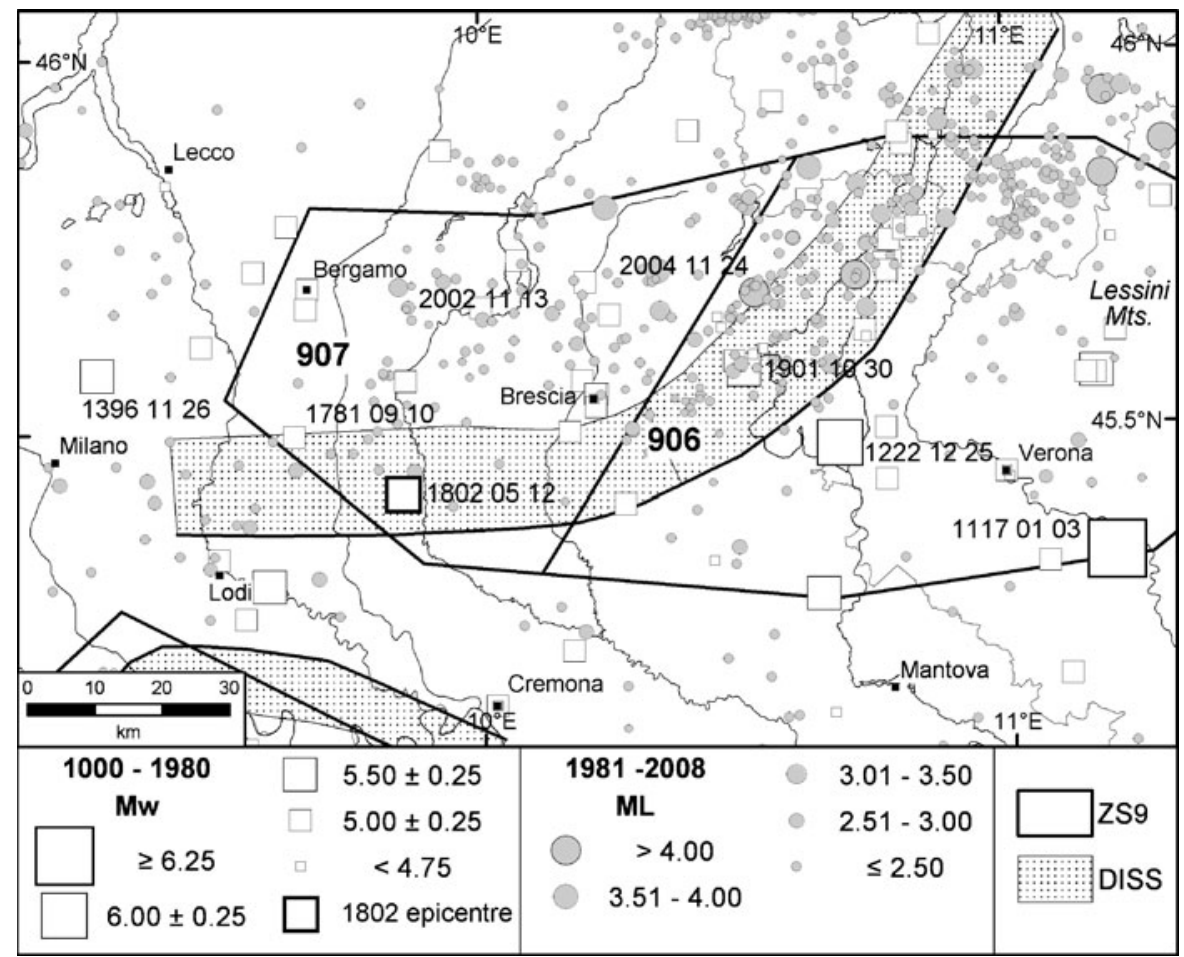

and (e) it provides a strong evidence for stretching the seismic source 907 of the seismogenic zonation ZS9 (Meletti et al. 2008) and a composite seismogenic source in the Database of Italian Seismogenic Sources, version 3 (DISS3; Basili et al. 2008) toward the west (Fig. 2) to incorporate its presumed source and other, unknown, similar ones.

For all these reasons, although the earthquake parameters seemed to be relatively well constrained, we decided to reinvestigate the event by searching for new documentary sources. The results have been then interpreted in terms of both Mercalli-Cancani-Sieberg (MCS; Sieberg 1930) and EMS98 (Gruenthal 1998) macroseismic scales. The first scale was used to ensure the homogeneity with the Italian database (Stucchi et al. 2007); the second one was used for allowing comparison with European data sets and to contribute building up a comparison dataset between the two scales.

The new intensity distribution was then used to assess the earthquake parameters using updated techniques, in the view of improving the comprehensive understanding of the event in relation to the seismogenic context.

\section{Context and state of the art}

\subsection{Historical and recent earthquakes}

In the eastern section of the Southern Alps, historical and recent seismicity is high in terms of both frequency of occurrence and energy released per event, with earthquakes defining a seismic belt at the foothills of the chain where the main active faults are located.

West of the Lessini Mountains, earthquakes are but a few and their epicenters located both at the border of the Alpine chain and in the area of the Po Plain, without any clear trend; historical and recent seismicity is nearly absent to the west of Milan (Fig. 2).

In this area, the CPTI04 catalog lists three events with $\mathrm{Mw} \geq 5.5$ in addition to the 1802 earthquake. The most recent one is the 30 October 1901 earthquake (Fig. 2); its epicenter, close to Salò (Lake Garda), and its magnitude ( $\mathrm{Mw}=$ $5.67 \pm 0.07)$ are well constrained, as they derive from 191 intensity data points (Boschi et al. 1997).

The 3 January 1117 (Veronese) and the 25 December 1222 (Brescia area) earthquakes are 
both located to the east of the 1802 earthquake, with respectively, Mw $6.49 \pm 0.15$ and $6.05 \pm 0.13$ according to CPTI04 (Fig. 2). They have been the object of extensive investigation since the 1980s.

All the studies on the 1117 earthquake (Magri and Molin 1986; Guidoboni 1984; Guidoboni and Boschi 1989; ENEL 1986; Boschi et al. 1997, 2000; Galadini et al. 2001; Galli 2005; Guidoboni et al. 2005; Guidoboni and Comastri 2005; Guidoboni et al. 2007) interpret it as a complex, not yet fully explained seismic sequence, on the basis of the wide area from which damage is reported. In spite of the fact that many records are available for an earthquake of that period, most of them report damage to single monumental buildings in many places of Northern Italy, which cannot be interpreted in a straightforward way. As a consequence, and although many studies agree that damage was particularly high in the area of Verona, the epicenter still floats in a large area around this city.

In a similar way, the epicentral location and the magnitude of the 1222 earthquake are affected by the difficulty of associating the effects to localities because damage is generically reported from the area of the Brescia diocese and was probably higher in its southern part (Boschi et al. 1995; Guidoboni and Comastri 2005). According to different interpretations, the epicenter of this earthquake wanders in the area between Brescia and Verona.

In the area west of the Lessini Mountains, CPTI04 lists 25 more earthquakes with $4.8 \leq$ $\mathrm{Mw} \leq 5.5$ (Fig. 2). Of these earthquakes, according to Stucchi et al. (2008), those occurred before 1700 are known through sparse traces consisting of information from one or two places only per event, and consequently, their epicentral locations are totally controlled by the only places from where comes the information. In particular, the 1396 event is located at Monza, where the only available record comes from, and it could be located elsewhere. Other earthquakes are to be referred to the foothill belt, while the epicenters of earthquakes like the 10 September 1781 one appear well constrained and located in the Po Plain.

It is to be stressed that according to the investigation performed in the probabilistic seismic hazard assessment of Italy (MPS Working Group 2004), the seismic history of the area west of the Lessini Mountains seems to be complete after 1300 for events with $\mathrm{Mw} \geq 6.0$ and since 1539 for events with $\mathrm{Mw} \geq 5.4$. The background for such assessment is found in Stucchi et al. (2004), who rely on the investigation on the completeness of site seismic histories at 15 places in Italy (Albini et al. 2001), including the place of Crema, not far from the epicenter of the 1802 earthquake.

According to the Catalogo della Sismicità Italiana-CSI (1981-2002; Castello et al. 2006) and the INGV Monthly Bulletin (2003-2008), recent earthquakes, characterized by low magnitudes $(2.5<\mathrm{ML}<3.5)$, occurr both at the Alps foothills and in the area of the plain. Those worth being recalled belong to the foothill area: the 13 November 2002, located a few kilometers from the southeastern shore of the Lake Iseo with Mw 4.29 (Pondrelli et al. 2004), and the 24 November 2004 earthquake, located to the northwest of Salò, close to the epicenter of the 1901 event, with Mw 5.00 (Pondrelli et al. 2007; Fig. 2).

\subsection{Tectonic setting}

The general tectonic style of the Southern Alps in Lombardy is characterized by WNW-ESE striking structures (Fig. 3). In the foothill area of the Southern Alps, a thrust and fold belt involves both outcropping Cretaceous terrains and buried Eocene to upper Miocene units (Castellarin et al. 1992; Fantoni et al. 2004). The regional structures are paired syncline-anticlines with a WNW-ESE trend and en-échelon arrangement (Fantoni et al. 2004). To the south, the structural units are buried under the thick sequence of Pliocene and Pleistocene deposits of the Po Valley Basin and are arranged in a south-verging system of imbricate units. In the middle sector of the Po Plain, regional folds resulting from the propagation of deep fault planes deform the Mesozoic units. At the southern tips of the thrusts, gentle anticlines are formed within the Tertiary clastic wedges. These folds are offset by the northward propagation of the younger external front of the north-verging Apennine thrusts to the northwest of Cremona (Fantoni et al. 2004). 
Fig. 3 Main tectonic features of the central Po Plain area and geological section (modified after Fantoni et al. 2004), epicenter of the 1802 earthquake (CPTI04), and seismogenic source models according to ZS9 (Meletti et al. 2008) and DISS3 (Basili et al. 2008). Individual seismogenic sources from DISS3 are shown also

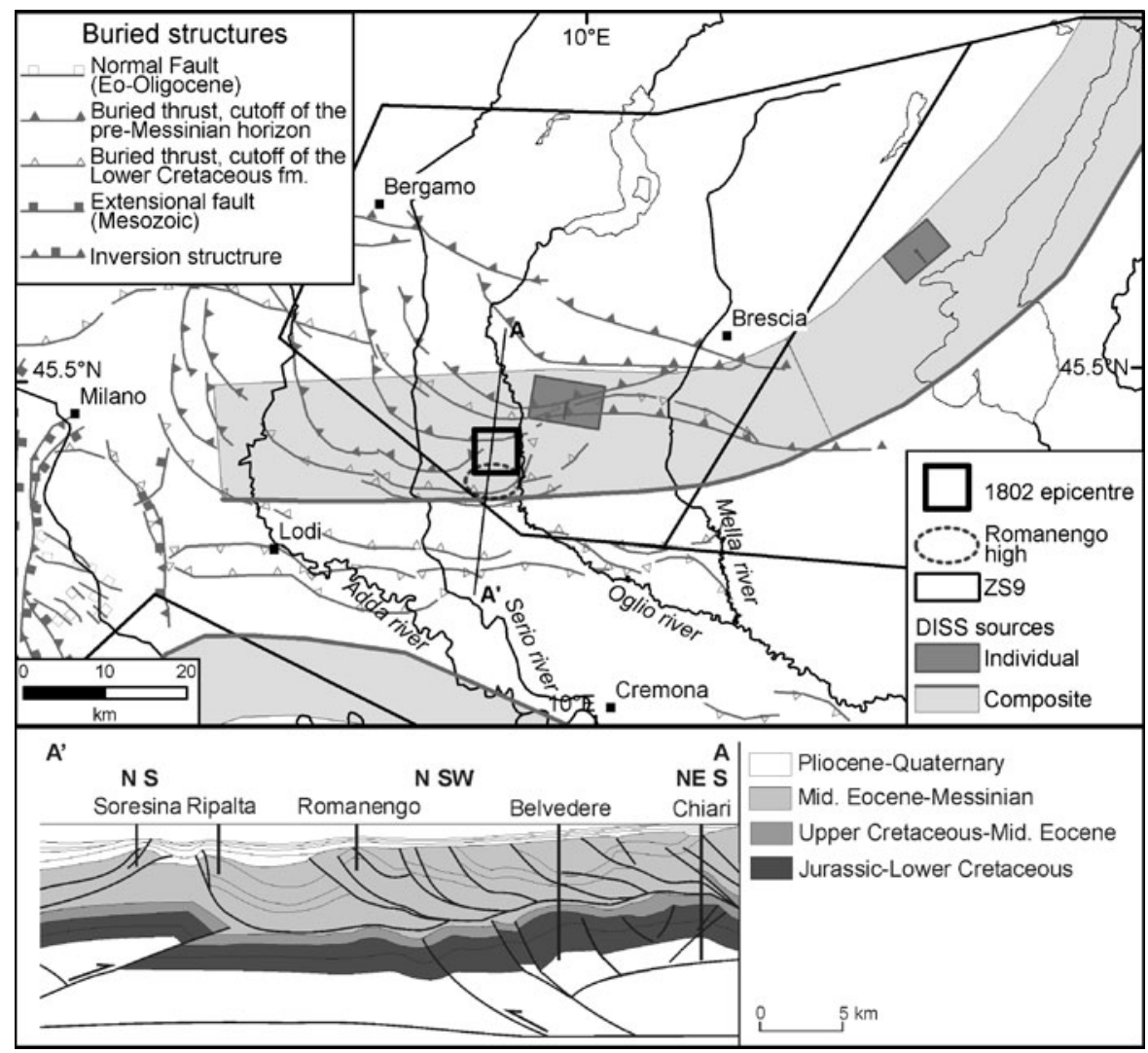

Due to this structural setting and to the features of the seismicity described previously, the straightforward identification of seismogenic structures results in difficulty. Since there is no direct surface evidence of active tectonics, only small deformations can be related to movements of the faults at depth (e.g., Desio 1965; Burrato et al. 2003; Galli 2005). In the area of the 1802 earthquake, several geomorphological features have been interpreted as indicative of active deformation in the subsurface. These features can be summarized as follows: (1) the Romanengo structural high described by Desio (1965), (2) the diversion of the Oglio river South of Orzinuovi, and (3) the presence of an abandoned channel of the river Oglio south of Soresina (Marchetti 1990).

On the other hand, seismic profiles (Pieri and Groppi 1981; Cassano et al. 1986; Fantoni et al. 2004, see the section in Fig. 3) identified more than a single deep thrust deforming the Quaternary deposits. No profile has a resolution sufficiently high to recognize the crosscutting relationships between the structures and the youngest deposits. Thus, there is not a single structure that can be selected as the candidate seismogenic fault of the 1802 earthquake (Fig. 3).

Burrato et al. (2003) explained the southeastward diversion of the Oglio river in the area to the northeast of Soresina with the uplift induced by an active EW-striking, S-verging blind thrust. According to Cassano et al. (1986), such a structure deforms Upper-Middle Pliocene sediments. Desio (1965) linked the so-called Romanengo structural high, a 8.5-km-long and $3.5-\mathrm{km}$-wide area elevated 3 to $7 \mathrm{~m}$ with respect to the plain and elongated in a NNW-SSE direction, to the activity of an anticline buried beneath it. Later, Galli (2005) suggested that the damage distribution of the 1802 earthquake is compatible with the geometry of the faulted anticline below the Romanengo high.

\subsection{Seismogenic models}

The 1802 is the main event of the zone 907 of the seismogenic zonation ZS9 (Meletti et al. 
2008), which represents a reduced legacy of the former zone 9 in the ZS4 (Meletti et al. 2000) (Figs. 2, 3), used by the Seismotectonics and Seismic Hazard Assessment of the Mediterranean Basin-SESAME project (Jiménez et al. 2001), too. The main faulting mechanism is inverse; the average depth is $8-12 \mathrm{~km}$. According to the MPS Working Group (2004), the maximum expected $\mathrm{Mw}$ is 5.9 from geological considerations; a conservative value of 6.14 was adopted in some branches of the logic-tree used for probabilistic seismic hazard analysis. The $b$ value is about 1.5. It has to be stressed that seven earthquakes, including the above-mentioned 1396 one (Mw 5.27), have conservatively been associated to the 907 zone even if their epicenters fall slightly out of it.

The DISS3 (Basili et al. 2008) identifies the seismogenic source of the 1802 earthquake as a NNE dipping low-angle $\left(25^{\circ}\right)$ thrust located $10 \mathrm{~km}$ to the northeast of the earthquake epicenter. The dimensions of this fault are compatible with a $\mathrm{Mw}$ 5.9 earthquake and a depth ranging from 1.5 to $4 \mathrm{~km}$. This source is part of a "composite seismogenic source," a category of sources defined in DISS as inferred structures based on regional geological data that are exploited well beyond the simple identification of active faults. The composite source, comprising the 1802 individual source, represents a S-verging blind thrust identified by Cassano et al. (1986) and Pieri and Groppi (1981).
It parallels the Alpine margin to the south between the Adda river and Brescia (Figs. 2, 3). The depth of this source ranges between 1 and $8 \mathrm{~km}$, and its maximum magnitude is the one estimated for the 1222 earthquake (Mw 6.2).

\subsection{The 1802 event in the previous studies}

The intensity distributions proposed by the previous studies (Brega et al. 1985; Boschi et al. 1997, 2000; Guidoboni et al. 2007) are to be considered fairly acceptable in comparison with what is known about similar events of the same time period in Italy. Brega et al. (1985) provided intensities at 49 places. The 24 places with $I \geq 6 \mathrm{MCS}$ are confined in a narrow, E-W elongated area in the northern part of the today province of Cremona, with 12 places with $I=8$ MCS located in the northeastern corner, to the west of the Oglio river (Fig. 4).

The earthquake was reappraised for the compilation of the CFTI (Boschi et al. 1997). This study integrated the information coming from sources already known to Brega et al. (1985) with records from contemporary newspapers published in Northern Italy and archival documentation about Orzinuovi, which became the most damaged place (I 8-9 MCS). The amount of intensity data became 66 (Fig. 4). The same intensity distribution was included in the updated versions
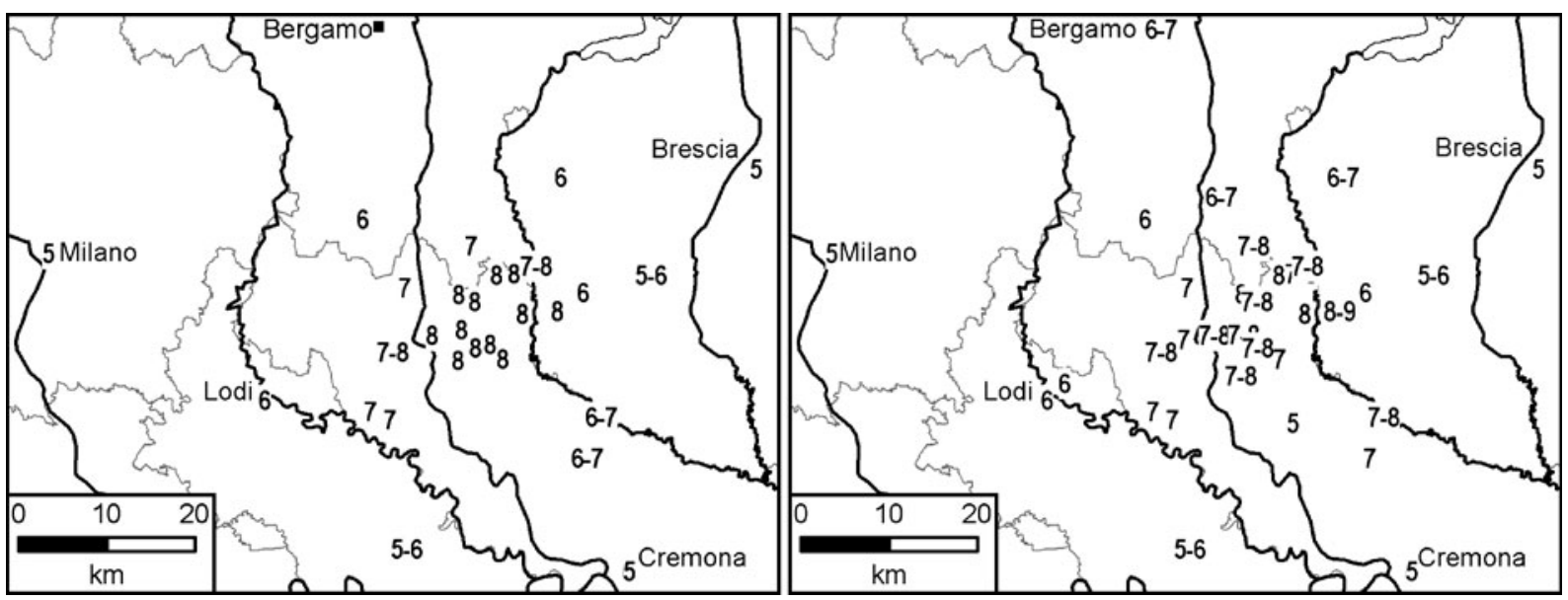

Fig. 4 Intensity distributions of the 1802 earthquake in the previous studies: left Brega et al. (1985), right Boschi et al. (1997) 
of the CFTI catalog (Boschi et al. 2000; Guidoboni et al. 2007) without any further improvement.

Although based on a well-performed historical research, both the distributions by Brega et al. (1985) and Boschi et al. (1997) show some gaps in the damaged area, especially to the south and south-east of the current epicenter, with scattered data in the area to the east of the Oglio river. Furthermore, some intensity assignments were based on scarcely informative records. As a matter of fact, in the 1980s and 1990s, seismologists used to assess sharp intensities values even when data did not allow it completely, as a result of the users' requests. Today, modern processing techniques of macroseismic data allow to handle range-intensity classes, such as 6 to 7 .

\section{The historical sources}

\subsection{Documentary sources}

The area affected by the earthquake roughly corresponds to the today provinces of Brescia, Bergamo, Lodi, and Cremona, which according to the Napoleonic administrative organization (Legge 1801; Decreto 1802) were enclosed by three departments: Mella (capital Brescia), Serio (Bergamo), and Alto Po (Cremona). Each department was ruled by a prefect representing the central government. The documents related to the departments are found in the state archives of the three former capitals; those related to the central administration of the Repubblica Italiana (1802-1805) were located in the State Archive of Milan but suffered serious losses during World War II.

In particular, are lost the damage surveys performed by engineer Girolamo Brioschi, appointed to estimate damage and repair costs according to the 5 August 1802 Government Ordinance (record no. 14582: ASBg 1802u; ASBs 1802q). With the exception of the survey about Casaletto and Melotta (ASBg 1802m) that survived to us, we know about the surveys because they are referred to in many documents; Brioschi's signature is visible in some documents that state the repair costs. The ordinance fixed that private citizens were to be assigned to the first and second classes according to their census; they were to be granted, respectively, the whole amount and the $50 \%$ of the repair costs. The third and fourth classes concerned, respectively, public buildings, for which some financial aid was foreseen, and those churches that could not afford the reparation.

On the other hand, letters exchanged among the central government, the prefects of the departments, and the local communities on earthquake damage and related expenses have survived. Among them springs out the 11 November 1802 circular letter, record no. 7005 (ASBg 1802ac), in which the prefect asked the local officers of the Department of Serio whether and what kind of damage each community had suffered on the occasion of the earthquake. This document has survived together with all the answers, thus supplying us with information on the earthquake effects in the whole department.

In addition, documentation referring to damage through the costs sustained to repair private and public buildings are available. Most of the documents refer in general to the amount of repair costs in terms of material and manpower but not reporting damage description nor the number of citizens and/or buildings that benefitted from the government relief. Some are simple receipts of the advance payments or of the total sum delivered to a community.

A summary of the investigated documents is presented in Table 1: the main contribution by each archive in terms of available documents is presented in Fig. 5. What is immediately evident is the absence of any documentation from the state archives concerning the territory of the Department of Alto Po.

\subsection{Narrative sources}

\subsubsection{Coeval leaflets, letters, diaries, and meteorological observations}

Out of the 51 pages of his Memoria istoricofisica (Historical-physical memoir), Caparrotti (1802) devoted less than ten pages to describing the 1802 earthquake and the rest to portraying his view of how an earthquake generates. What makes this leaflet a valuable testimony is that 


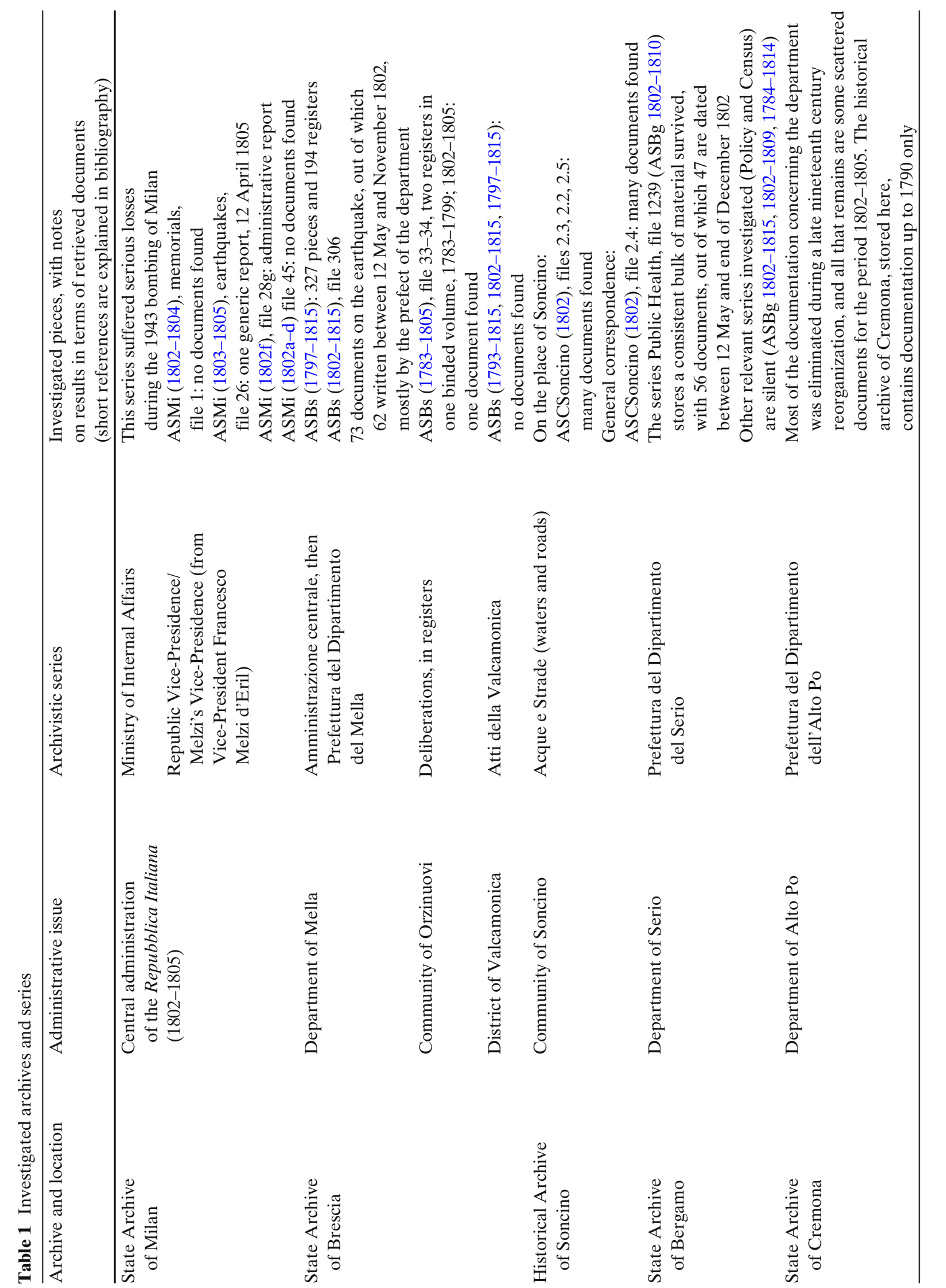




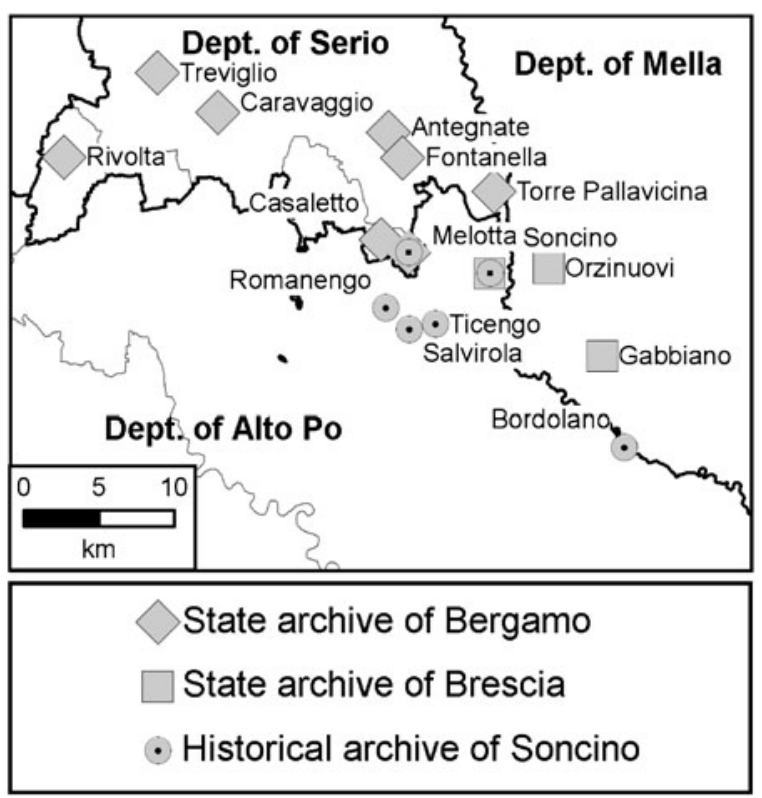

Fig. 5 Documentary sources according to their provenance. Thick lines show the borders of the Napoleonic departments; thin lines represent today provinces

it supplies the results of a field survey made by the author together with a "Giovanni Battista Monticelli Strada." Caparrotti gives no day nor month when the leaflet was published, but it is apparent that their survey was carried out close to the earthquake occurrence. Unfortunately, the report is very short, and effects and places are summarized in a cumulative description of collapsed houses, truncated bell towers, and fissures in the walls, followed by a list of the damaged places. Most of the information in the leaflet written by Balis (1802) coincides with the text by Caparrotti, with the addition of some places and some differences in the similarly generic description of the effects.

Worth to be mentioned are some personal memories and correspondence: (1) Memorie di Casalmaggiore from 1787 to 1827 (Morisio 17871827); (2) Memorie mie in 16 volumes from 1750 to 1815 ; in 1802, the author was living at Pavia (Rosa 19th century); (3) Memorie on his life, by Luigi Massari (18th-19th century), a civil servant in Crema, who wrote extensive memories of his hometown, inserting transcriptions of official documents produced or received by the munic- ipal council; and (4) the 18 May 1802 letter by a P.M. Rusconi, living in Milan, to his friend G. Romegialli in Sondrio, northern Lombardy (Rusconi 1802).

\subsubsection{Coeval press}

Most of the newspapers printed at the time in Northern Italy reported the earthquake. The first was Il Corriere Milanese (1802a), which in a correspondence from Milan on 13 May, stated that it was strongly felt there. The following issue (Il Corriere Milanese 1802b, 17 May) added that the most damaged places were Soncino, Crema, and Orzinuovi. The Gazzetta Universale (1802a, 1802b) did likewise, while other periodicals reported information concerning their respective territories: the Journal de Turin (1802) for Turin and the Gazzetta Nazionale della Liguria (1802) for Genoa and Liguria; according to the Gazzetta di Bologna (1802), at Orzinuovi, 400 out of 500 buildings had collapsed. The Moniteur Universel (1802) puts Brescia among the seriously damaged places.

\subsubsection{Later narrative sources using coeval documents}

Two later essays drawing on coeval documents described the damage suffered by Orzinuovi and Soncino, two of the most damaged places: (a) the essay on the churches of Orzinuovi by the parish priest Francesco Perini (19th century), who largely drew on the documents of the local parish archives, and (b) the history of Soncino by Galantino (1869), written making use of his close acquaintance with the documents of the local archive and of the collection of letters exchanged by the local nobleman Giovan Battista Della Volta with his relatives. Galantino devoted many pages to the earthquake, listing the foreshock and the many aftershocks, and described the damage and the restoration works by transcribing coeval documents. Some of these documents are today lost and would not have been otherwise known to us. His essay represented the reference study of the 1802 earthquake for the twentieth century seismological studies. 


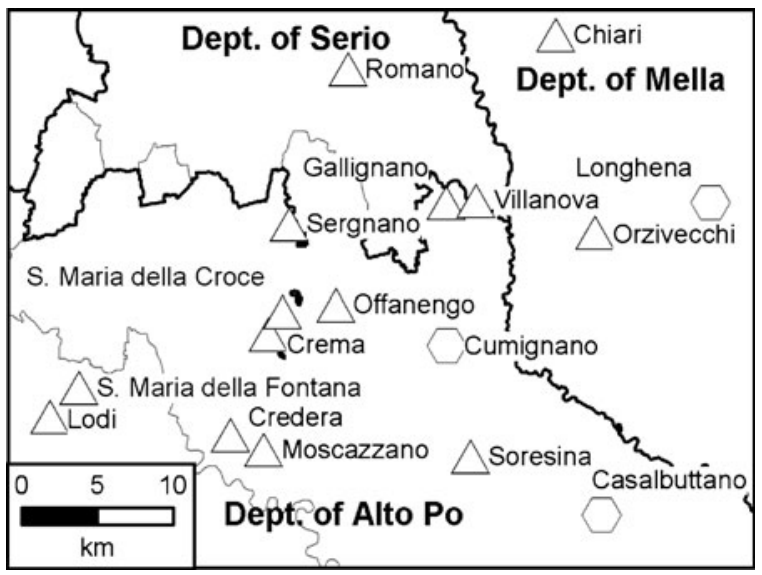

Fig. 6 Coeval narrative sources (triangles), later local histories (hexagons), and places about which they contribute information. Thick lines show the borders of the Napoleonic departments; thin lines represent today provinces

Other local histories written shorthly after the 1802 earthquake do not significantly contribute. Most of them mention the event in a very general way, without giving any reference to their sources (Manini 1819-1820; Ceruti 1834; Grandi 1856; Sforza Benvenuti 1859). Figure 6 show the places for which the narrative sources are essential.

\section{The effects distribution}

\subsection{Overview}

The most damaged place was Orzinuovi. The municipal council in a letter written on 12 May 1802 reported to the central authorities that:

The churches of St Francesco, St Domenico and Madonna knocked down by the blows of such a severe punishment, all the rest touched so much that threatens to fall any moment, half of the houses fallen, half made uninhabitable by the cracks that can not be repaired in any other way than by rebuilding them (ASBs 1802a).

The documents concerning Orzinuovi come from its historical archive, today stored at the State Archive of Brescia. They concern the exchange between the local and central authorities about assistance and financial support, as well as the criteria to allocate the funds (ASBs $1802 \mathrm{~d}-\mathrm{n}$, 1802q). They were already used by Boschi et al. (1997) and Guidoboni et al. (2007). The scenario of damage is further confirmed by the prefect of the department of Mella, who in June 1802 went from Brescia to Orzinuovi for a survey and wrote back to the Minister of the Internal Affairs:

Had I not been there in person I would not have been easily persuaded of the sorrowful, and pitiable situation of this wretched place. I assure you that it will be irremediably lost if the Government will not increase the generous funds already decreed (ASBs 1802p).

Perini (19th century) wrote about the three churches mentioned by the 12 May document above ASBs (1802a):

1. On the church of St. Francesco (abolished in 1810 and then demolished together with the tower and part of the cloisters):

On the occasion of the 1802 earthquake the vault of the church collapsed: it was then reconstructed, and when the scaffolding was removed it collapsed again, and was rebuilt

2. On the church of St. Domenico, also known as Santa Maria delle Grazie:

On its foundation the church was dedicated to the Blessed Vergin of Mercies [...] and since the Dominicans served there, it was commonly called $\mathrm{St}$ Domenico [...] During the 12 May 1802 earthquake the vault of the church collapsed, and it was reconstructed at the expenses of the 'Repubblica Italiana' [the government], as one can realize from the painted inscription that can be read [at the time of Perini] above the arch of the high altar: 'This church ruined on the 12th of May 1802 / and it ruined because of an earthquake / the charity of the Republic made possible its reconstruction / by means of the public money itself' (Perini 19th century). 
3. On the church of the Madonna, Perini gives no specific information about any damage suffered because of the earthquake.

There is a "negative" information also, about the church of St. Mary of the Suffrage, or the Dead, which alone did not suffer any damage (Perini 19th century).

Soncino, in the department of Alto Po, was among the most damaged places. At Soncino, many churches were shattered, such as the Chapter near St. Pietro, the church of St. Giacomo, the church of St. Pietro extra moenia (light damage), the monastery of St. Paolo, and the churches of Santa Maria delle Grazie and San Bernardo alla Campagna; the bell tower of the Parish ("pieve") lost half of its steeple, and the parish house was damaged as well. The tower of the Pretorio palace split by wide fissures; damage was suffered by the gate of St. Giuseppe; the Pretorio palace had to be partly demolished and restored. Some private buildings ruined the same 12 May, and many of the others had to be propped up with afresh cut trees, as clearly stated in a document of 22 May (ASBs 1802k). Many tumbledown houses had to be demolished.

The first sum of money was refunded in November 1802, consisting of 53,874 lire (ASCSoncino 1802o). Reading the many documents of the local archive, it appears that for some months, the town was the theater of operations of masons, blacksmiths, and laborers. The Pretorio palace had to be heavily restored, as well as many buildings facing the main square (ASCSoncino 1802a-c, e, g-h, k, m-n, 1802d, f, i-j, l, u, 1803b-d). According to Galantino (1869), who probably could examine a large and comprehensive bulk of coeval documents, the sum of money allotted to Soncino was 79,780 lire out of a total of 118,870 requested through the survey.

An anomalous case is Gallignano. This place was never an autonomous commune but a suburb of Soncino, seat of the parish of St. Peter the Apostle. With no officers to produce them, there are no documentary sources. It is described as seriously damaged in the essay by Caparrotti (1802), and Galantino (1869) reported that the sum of 28,302 lire was allocated to Gallignano for the damage suffered, according to the four classes defined by the 5 August 1802 ordinance (ASBs 1802q).

In the southeastern corner of the Department of Serio, close to the border with the Department of Mella, lie the places of Casaletto and Melotta. The municipal authorities wrote on 13 May (ASBg 1802d) that if some restoration were not planned, in the very near future, the two places were going to become "nothing else than a heap of pebbles." The several documentary sources always consider these two places together. A survey was done locally (ASBg 1802k), and on 4 June 1802, a first estimate of the damages reached 3,250 lire for both places (ASBg 1802m). After a dense exchange of documents between local and central authorities, on 19 September 1803, the final report on the allotted sums of money stated that Casaletto got 10,202 lire and Melotta 1,150. In both cases, most of the costs went into restoring the churches and the parish houses (Fig. 7).

Close to Casaletto and Melotta, there is the place of Fontanella, the damage at which is described in many documents of the department of Serio. Of great interest is the 21 May letter (ASBg 1802f), reporting that a small house ruined to the ground, and it belonged to the peasant Locatelli, who died in it together with his young daughter; another house partially collapsed, the municipal building was tumbledown, there was a fissure in the main tower, many in the parish church, and the rest of the place was seriously shaken. One of the final documents about the distribution of financial aid, dated October 1803, reports for Fontanella that 25 owners were refunded, plus the parish and the commune, for a total of 9,290 lire (ASBg 1803i).

The effects at Torre Pallavicina, also in the department of Serio, are testified in a series of documents of at least 20 different properties damaged (ASBg 1802e, 1802h, 18021, 1802n-q, 1802t, 1802v, 1802aa-ab, 1802as, 1802av, 1803a, 1803d). The final version of the survey (ASBg 1803h-i) confirms a scenario of serious damage: private citizens got a refund of more than 11,000 lire, while 985 lire were destined to the restoration of the church and the oratory.

The place of Antegnate is mentioned by the documentary sources of the Department of Serio, from July 1803 only: unfortunately, all the 


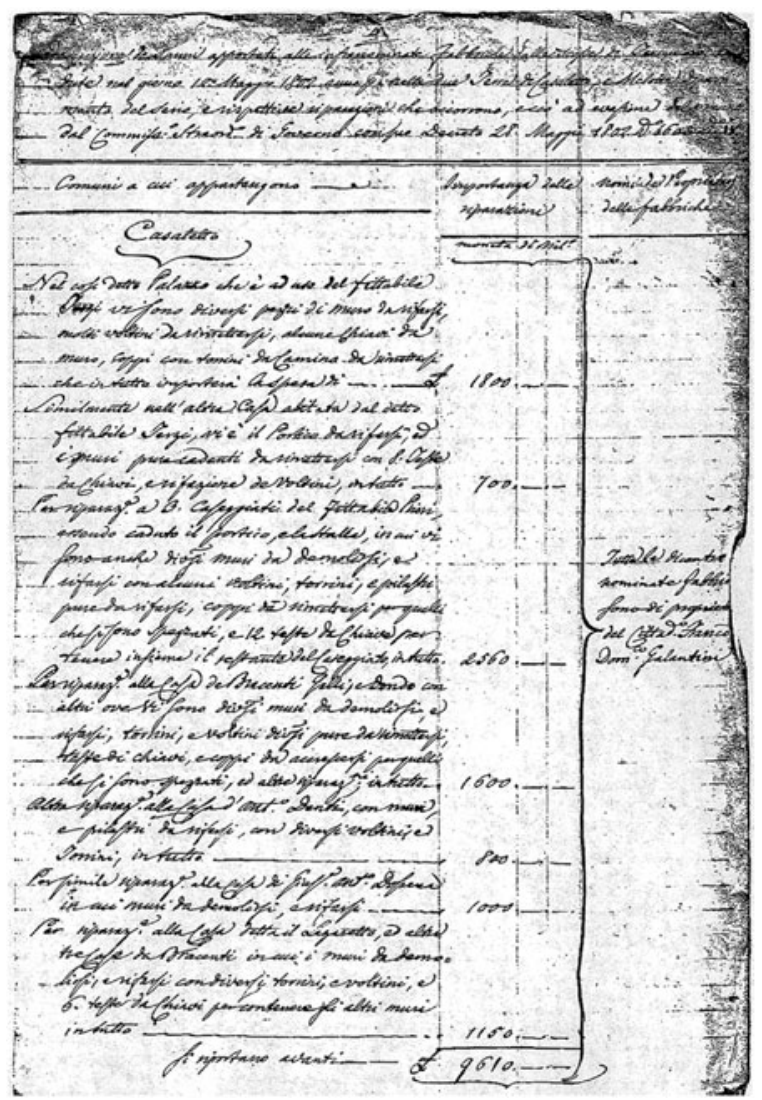

Fig. 7 First page of the damage survey at Casaletto, including the estimate of the money needed to repair the buildings (ASBg 1803h)

information concerns the sum of money needed for repairing the damage. A first report, dated 11 July 1803 (ASBg 1803d), gives the sum of 588 lire. The final prospect of October 1803 (ASBg 1803i) gives a slightly higher amount, 643 lire, and specifies that this money was used to repair two houses (243 lire) and one church (400 lire).

The place of Gabbiano, today Borgo San Giacomo, was damaged, as it is mentioned in two documents from the central government together with Orzinuovi (ASBs 1802t, 1802u) concerning the allotment of funds to restore the damaged properties. The documentation concerning the commune, stored at the local archive, does cover the period of interest but, unfortunately, is completely silent about the 1802 earthquake.

Passing the border to the south and entering again the Department of Alto Po, Crema was, until 1797, an enclave pertaining to the Republic of Venice. No documentary sources were found; however, Massari (18th-19th century) wrote that the damage at Crema consisted in some buildings crumbled into pieces and many chimneys collapsed. The municipal authorities immediately allocated some 30,000 lire to repair (1) the Torrazzo (the municipal tower with the clock), (2) the bell tower of the romanesque cathedral, and (3) the damage to the renaissance church at Santa Maria della Croce, $3 \mathrm{~km}$ far from the walls of the town.

Apart from Soncino and Crema, for most of the places in the Department of Alto Po, the information is still scarce. The three places of Romanengo, Bordolano, and Salvirola are mentioned in a comprehensive report on the financial aid decreed by the government (ASCSoncino 1802o). Five more places, Villanuova, Casalbuttano, Credera, Offanengo, and Cumignano, were slightly damaged according to what was found in narrative sources (Balis 1802; Manini 18191820; Galantino 1869). Finally, for Ticengo, there are contradictory observations: Caparrotti (1802) wrote it had been seriously damaged, while Balis (1802) mentioned it among the slightly damaged places. The documentary evidence (ASCSoncino 1802o) concerns only the amount given for the restoration of Ticengo: it is smaller-514 lire on 10 November 1802 (ASCSoncino 1802o) increased to 833 lire in July 1803, according to Galantino (1869) - than that agreed for other damaged places, thus confirming the information coming from Balis (1802).

Massari (18th-19th century) was not at Crema when the earthquake occurred. He was traveling on a coach passing Codogno, some $30 \mathrm{~km}$ to the south; the noise of the coach made it impossible for him to feel the earthquake, but he saw people leaving their houses and looking upward and immediately related this behavior to the occurrence of an earthquake. This is the only testimony about the earthquake effects at Codogno.

In some 44 places, the damage was not important or simply none. The information about 20 out of these 44 places comes from the answers to the circular no. 7005 of 11 November 1802 (ASBg 1802ac). They are Alzano Maggiore (Alzano Lombardo), Bagnatica, Entratico, Breno, Martinengo, Villa d'Ogna, Ardese (Ardesio), Almenno (Almenno San Salvatore), Castro, 
Gandino, Piazza (Piazza Brembana), Ponte San Pietro, Rivolta (Rivolta d'Adda), S. Stefano (Carobbio degli Angeli), Somasca (Vercurago), Tagliuno (Castelli Calepio), Treviglio, Valle in Nembro (Nembro), Verdello, and Zogno. For other places, the letters, written by the local authorities on occasions other than the answer to the circular, describe with a good precision the effects of the earthquake, as in Bergamo (ASBg ASBg:1802c), Caravaggio (ASBg 1802a), Cepino (ASBg 1802ar, 1803b-c), Lovere (ASBg 1802b), and Brescia (1802b).

The information about the 19 remaining places comes from narrative sources only: Morcelli (1780-1815), Arnaldi Tornieri (17671822), Bianchi (1772-1821), Biffignandi (17961820), Fenini (18th-19th century), Monti (18th19th century), Bugoni (1801-1852), Cassinis (1802), Churer Zeitung (1802), Giovio (1802), Penada (1808), Tommaselli (1815), Mercalli (1883), Boccalletti (19th century), Lampugnani (19th century), and Anonymous (19th century).

Finally, for Milan, we have three independent sources of information: (1) Il Corriere Milanese (1802a) on the 13 May issue reported that the earthquake was strongly felt; (2) Morisio (17871827) echoed the same news, and (3) Rusconi (1802) wrote that the downtown school-building of Brera, were he was studying, swayed to and fro.

\subsection{Intensity assessment}

The earthquake records newly retrieved were thoroughly organized and reappraised, to make the best out of the information on earthquake effects they contain when it came to assess macroseismic intensity.

Two macroseismic scales have been used: (1) MCS (Sieberg 1930), to guarantee the homogeneity with the Italian database (Stucchi et al. 2007), and (2) EMS98 (Gruenthal 1998), to compare our data with other European datasets, as well as to contribute building up a comparison dataset between the two scales.

By means of some case histories, the process of interpretation of the records is described, focusing on the difficulties arising from the nonavailability of all the information needed to unequivocally assess an intensity degree. In particular, the infor- mation about the types of buildings is generic, and the main assumption made was that the damage has to be attributed in the same proportion to vulnerability classes A and B in EMS98. The intrinsic uncertainty of the data are reflected in both scales by using a range (e.g., 6 to 7 ) rather than a full degree (6 or 7$)$.

Orzinuovi had slightly more than 4,000 inhabitants at the time of the earthquake, and all the records concur in drawing a situation of widespread damage, which definitely included collapses and structural damage, to private houses and churches. The information supplied by a contemporary newspaper (Gazzetta di Bologna 1802) that out of 500 buildings, 400 had been severely damaged is considered an exaggeration and was not taken into account. The overall records allowed us to assess in MCS scale $I 8-9$, as a range between 8 ( $25 \%$ of buildings seriously damaged) and 9 (collapses and more than $25 \%$ of buildings seriously damaged). In EMS98, although the records did not carry the information on the exact percentage of buildings to be related to each grade of damage, the overall description could, in our opinion, fit with the definition of the intensity degree 8.

Casaletto and Melotta are the only two places for which the surviving documentation is very similar to a house-by-house recognition of the damage (Fig. 7). Both places were small settlements, since Casaletto had less than 400 inhabitants (Cremona 2000), and Melotta was even smaller. The records supply a scenario of serious damage and resulted in an assessment of $I 8$ MCS. The EMS98 assessment in this case could not but reflect uncertainty between the definitions pertaining to degrees 7 and 8, and consequently, for both Casaletto and Melotta, in EMS98, an I 7-8 was assessed.

The records for Fontanella, a settlement with less than 1,500 inhabitants, and Torre Pallavicina, about 1,000 inhabitants, are less detailed with respect to damage descriptions. In any case, the overall information converged in estimates similar to Casaletto and Melotta in both scales, I 8 MCS and I 7-8 EMS98.

In the case of Antegnate, around 1,000 inhabitants, the records concern damage suffered by two houses and one church only. Consequently, 
the intensity assessment in MCS took into account the uncertainty about the settlement having lightly (6 MCS) and strongly suffered (7 MCS) and resulted in $I$ 6-7. In using EMS98, we estimated that the grade of damage consistent with the costs documented could have not been structural, but ranging between 1 and 2 as a maximum, and we assessed $I 6$.

About Romanengo, Bordolano, Salvirola, Villanuova, Casalbuttano, Credera, Offanengo, Cumignano, and Ticengo, the information was not considered sufficient to assess an intensity degree. For the sake of completeness, they have been included in the list of affected places and have been attributed the code " $\mathrm{D}$," to account for the generic description of damage that the historical macroseismic records supply.

Records on Bergamo, Breno, Cepino, Lodi, Martinengo, Moscazzano, Sergnano, and Soresina did not allow us to quantify the distribution and the type of damage. Such uncertainty was expressed by assessing I 5-6 MCS. In EMS98, only the records about Cepino, Lodi, Martinengo, and Moscazzano could fit in with the definition of $I$ 5 EMS98, as it includes damage of grade 1 to a few buildings of vulnerability classes A and B. To the remaining, it was attributed the same level of uncertainty as in MCS, and intensity was assessed as I 5-6 EMS98.

In all, the collected and interpreted records were turned into observations about 94 places affected by the 1802 earthquake. The available information allowed us to assess the macroseismic intensity at 64 places, to estimate for nine places that they had suffered damage (D), while at the 21 remaining ones, only a generic "felt" $(F)$ was assigned. Table 2 shows the complete list of the 94 places and the respective intensities in MCS and EMS98. The intensity distribution in MCS scale is shown in Fig. 8.

The intensity values in the two different scales result to be very similar, with differences represented only by uncertainties between full degrees in both scales. This similarity is supported by what Musson et al. (2010) conclude about the Cancani family scales, to which both MCS and EMS98 belong: such scales "are more or less equivalent in values" and "it might be wondered why any one should be preferable to any other."

\section{Earthquake parameters}

Several methods to derive earthquake parameters from macroseismic intensity data have been developed in time, from hand-drawn isoseismal maps to modern computer codes that use macroseismic data points. Modern codes are mainly based on the comparison of the intensity distribution of an earthquake with an attenuation model and the analysis of the differences.

Following the most recent trends (e.g., in the framework of the European Union "Network of Research Infrastructures for European Seismology"-NERIES project), we decided to apply two methods:

1. The method developed by Bakun and Wentworth (BW) (1997)

2. The "Boxer" code (Gasperini et al. 1999) in the 3.3 release (2004)

The two methods use different approaches as regards both the determination of the epicentral coordinates and the magnitude; they can be considered as independent.

The BW method evaluates the epicenter as the location of the minimum of the $M$ residuals calculated on a grid of trial locations with a selected attenuation model $I=f(M$, epicentral distance). In the Boxer method, the epicenter corresponds to the average of the coordinates of the data points pertaining to the highest intensity class.

The magnitude calculated by the BW method, calibrated to equal moment magnitude, is the mean $M$ value at the obtained epicenter. The Boxer code computes a magnitude value, also calibrated against $\mathrm{Mw}$, as the weighted average of the Mw values obtained from the felt area of each intensity class according to the formula by Sibol et al. (1987).

The Boxer code computes also the seismogenic box, i.e., a rectangular area, centered on the calculated epicenter, that represents the surface projection of the fault rupture that caused the earthquake, assumed with a dip of $45^{\circ}$. The dimensions of the box are obtained from the computed $\mathrm{Mw}$ through the application of the empirical relations by Wells and Coppersmith (1994); the azimuth and its uncertainty are obtained from the spatial distribution of the highest intensity data points. 
Table 2 Places and intensity (MCS scale and EMS98) for the 12 May 1802 earthquake

\begin{tabular}{|c|c|c|c|c|c|}
\hline Place-name in 1802 & Place-name today & Lat & Lon & $I \mathrm{MCS}$ & $I$ EMS \\
\hline Orzinuovi & Orzinuovi & 45.402 & 9.924 & $8-9$ & 8 \\
\hline Casaletto & Casaletto di Sopra & 45.420 & 9.782 & 8 & $7-8$ \\
\hline Fontanella & Fontanella & 45.469 & 9.801 & 8 & $7-8$ \\
\hline Gallignano & Gallignano & 45.439 & 9.837 & 8 & $7-8$ \\
\hline Melotta & Melotta & 45.412 & 9.805 & 8 & $7-8$ \\
\hline Soncino & Soncino & 45.399 & 9.874 & 8 & $7-8$ \\
\hline Torre Pallavicina & Torre Pallavicina & 45.448 & 9.878 & 8 & $7-8$ \\
\hline Crema & Crema & 45.362 & 9.686 & 7 & 7 \\
\hline Antegnate & Antegnate & 45.484 & 9.789 & $6-7$ & 6 \\
\hline Gabbiano & Borgo San Giacomo & 45.349 & 9.969 & $6-7$ & 6 \\
\hline Bordolano & Bordolano & 45.294 & 9.986 & $\mathrm{D}$ & $\mathrm{D}$ \\
\hline Casalbuttano & Casalbuttano ed Uniti & 45.252 & 9.965 & $\mathrm{D}$ & $\mathrm{D}$ \\
\hline Credera & Credera Rubbiano & 45.302 & 9.653 & $\mathrm{D}$ & $\mathrm{D}$ \\
\hline Cumignano & Cumignano sul Naviglio & 45.354 & 9.836 & $\mathrm{D}$ & $\mathrm{D}$ \\
\hline Offanengo & Offanengo & 45.379 & 9.743 & $\mathrm{D}$ & $\mathrm{D}$ \\
\hline Romanengo & Romanengo & 45.379 & 9.785 & $\mathrm{D}$ & $\mathrm{D}$ \\
\hline Salvirola & Salvirola & 45.353 & 9.781 & $\mathrm{D}$ & $\mathrm{D}$ \\
\hline Ticengo & Ticengo & 45.369 & 9.827 & $\mathrm{D}$ & $\mathrm{D}$ \\
\hline Villanova & Villanuova & 45.440 & 9.862 & $\mathrm{D}$ & $\mathrm{D}$ \\
\hline Alzano di Sopra & Alzano Lombardo & 45.734 & 9.730 & 6 & 6 \\
\hline Bagnatica & Bagnatica & 45.663 & 9.782 & 6 & 6 \\
\hline Caravaggio & Caravaggio & 45.497 & 9.644 & 6 & 6 \\
\hline Chiari & Chiari & 45.538 & 9.931 & 6 & 6 \\
\hline Entratico & Entratico & 45.705 & 9.875 & 6 & 6 \\
\hline Orzivecchi & Orzivecchi & 45.420 & 9.962 & 6 & 6 \\
\hline Santa Maria della Croce & Santa Maria della Croce & 45.375 & 9.698 & 6 & 6 \\
\hline Villa d'Ogna & Villa D’Ogna & 45.906 & 9.930 & 6 & 6 \\
\hline Bergamo & Bergamo & 45.694 & 9.670 & $5-6$ & $5-6$ \\
\hline Breno & Breno & 45.957 & 10.303 & $5-6$ & $5-6$ \\
\hline Cepino & Cepino & 45.805 & 9.536 & $5-6$ & 5 \\
\hline Lodi & Lodi & 45.314 & 9.501 & $5-6$ & 5 \\
\hline Martinengo & Martinengo & 45.570 & 9.768 & $5-6$ & 5 \\
\hline Moscazzano & Moscazzano & 45.293 & 9.681 & $5-6$ & 5 \\
\hline Sergnano & Sergnano & 45.427 & 9.704 & $5-6$ & $5-6$ \\
\hline Soresina & Soresina & 45.288 & 9.855 & $5-6$ & 5 \\
\hline Almenno & Almenno San Salvatore & 45.750 & 9.587 & 5 & 5 \\
\hline Brescia & Brescia & 45.544 & 10.214 & 5 & 5 \\
\hline Casalmaggiore & Casalmaggiore & 44.988 & 10.421 & 5 & 5 \\
\hline Castro & Castro & 45.803 & 10.066 & 5 & 5 \\
\hline Codogno & Codogno & 45.161 & 9.705 & 5 & 5 \\
\hline Como & Como & 45.810 & 9.084 & 5 & 5 \\
\hline Cremona & Cremona & 45.136 & 10.024 & 5 & 5 \\
\hline Gandino & Gandino & 45.810 & 9.902 & 5 & 5 \\
\hline Longhena & Longhena & 45.437 & 10.060 & 5 & 5 \\
\hline Lovere & Lovere & 45.812 & 10.070 & 5 & 5 \\
\hline Milano & Milano & 45.464 & 9.190 & 5 & 5 \\
\hline Pavia & Pavia & 45.189 & 9.160 & 5 & 5 \\
\hline Piazza & Piazza Brembana & 45.948 & 9.671 & 5 & 5 \\
\hline Ponte San Pietro & Ponte San Pietro & 45.697 & 9.588 & 5 & 5 \\
\hline Rivolta & Rivolta d'Adda & 45.471 & 9.513 & 5 & 5 \\
\hline Romano & Romano di Lombardia & 45.519 & 9.755 & 5 & 5 \\
\hline S.Stefano & Carobbio degli Angeli & 45.665 & 9.830 & 5 & 5 \\
\hline Santa Maria della Fontana & Fontana & 45.331 & 9.526 & 5 & 5 \\
\hline
\end{tabular}


Table 2 Places and intensity (MCS scale and EMS98) for the 12 May 1802 earthquake

\begin{tabular}{|c|c|c|c|c|c|}
\hline Place-name in 1802 & Place-name today & Lat & Lon & $I \mathrm{MCS}$ & $I \mathrm{EMS}$ \\
\hline Somasca & Somasca & 45.811 & 9.429 & 5 & 5 \\
\hline Tagliuno & Castelli Calepio & 45.640 & 9.903 & 5 & 5 \\
\hline Treviglio & Treviglio & 45.521 & 9.593 & 5 & 5 \\
\hline Valle in Nembro & Nembro & 45.743 & 9.759 & 5 & 5 \\
\hline Verdello & Verdello & 45.605 & 9.630 & 5 & 5 \\
\hline Vigevano & Vigevano & 45.317 & 8.856 & 5 & 5 \\
\hline Zogno & Zogno & 45.793 & 9.662 & 5 & 5 \\
\hline Alessandria & Alessandria & 44.913 & 8.615 & 4 & 4 \\
\hline Genova & Genova & 44.419 & 8.898 & 4 & 4 \\
\hline Mantova & Mantova & 45.152 & 10.775 & 4 & 4 \\
\hline Ostiglia & Ostiglia & 45.066 & 11.137 & 4 & 4 \\
\hline Padova & Padova & 45.407 & 11.876 & 4 & 4 \\
\hline Piacenza & Piacenza & 45.052 & 9.693 & 4 & 4 \\
\hline Salò & Salò & 45.606 & 10.522 & 4 & 4 \\
\hline Verona & Verona & 45.438 & 10.994 & 4 & 4 \\
\hline Vicenza & Vicenza & 45.549 & 11.549 & 4 & 4 \\
\hline Voghera & Voghera & 44.993 & 9.010 & 4 & 4 \\
\hline Asti & Asti & 44.899 & 8.206 & $\mathrm{~F}$ & $\mathrm{~F}$ \\
\hline Bardi & Bardi & 44.630 & 9.730 & $\mathrm{~F}$ & $\mathrm{~F}$ \\
\hline Bern & Bern & 46.948 & 7.450 & $\mathrm{~F}$ & $\mathrm{~F}$ \\
\hline Bologna & Bologna & 44.498 & 11.340 & $\mathrm{~F}$ & $\mathrm{~F}$ \\
\hline Brivio & Brivio & 45.741 & 9.447 & $\mathrm{~F}$ & $\mathrm{~F}$ \\
\hline Camaiore & Camaiore & 43.940 & 10.304 & $\mathrm{~F}$ & $\mathrm{~F}$ \\
\hline Castellucchio & Castellucchio & 45.150 & 10.647 & $\mathrm{~F}$ & $\mathrm{~F}$ \\
\hline Chiavari & Chiavari & 44.317 & 9.322 & $\mathrm{~F}$ & $\mathrm{~F}$ \\
\hline Chur & Chur & 46.851 & 9.538 & $\mathrm{~F}$ & $\mathrm{~F}$ \\
\hline Correggio & Correggio & 44.771 & 10.779 & $\mathrm{~F}$ & $\mathrm{~F}$ \\
\hline Gallarate & Gallarate & 45.659 & 8.793 & $\mathrm{~F}$ & $\mathrm{~F}$ \\
\hline Genève & Genève & 46.205 & 6.152 & $\mathrm{~F}$ & $\mathrm{~F}$ \\
\hline Legino & Legino & 44.294 & 8.456 & $\mathrm{~F}$ & $\mathrm{~F}$ \\
\hline Lugano & Lugano & 46.003 & 8.948 & $\mathrm{~F}$ & $\mathrm{~F}$ \\
\hline Moneglia & Moneglia & 44.240 & 9.488 & $\mathrm{~F}$ & $\mathrm{~F}$ \\
\hline Novi & Novi Ligure & 44.764 & 8.788 & $\mathrm{~F}$ & $\mathrm{~F}$ \\
\hline Parma & Parma & 44.801 & 10.329 & $\mathrm{~F}$ & $\mathrm{~F}$ \\
\hline Savona & Savona & 44.307 & 8.480 & $\mathrm{~F}$ & $\mathrm{~F}$ \\
\hline Trogen & Trogen & 47.400 & 9.467 & $\mathrm{~F}$ & $\mathrm{~F}$ \\
\hline Venezia & Venezia & 45.438 & 12.335 & $\mathrm{~F}$ & $\mathrm{~F}$ \\
\hline Zürich & Zürich & 47.372 & 8.540 & $\mathrm{~F}$ & $\mathrm{~F}$ \\
\hline Rovereto & Rovereto & 45.888 & 11.037 & 3 & 3 \\
\hline Torino & Torino & 45.070 & 7.674 & 3 & 3 \\
\hline
\end{tabular}

The Boxer code does not require any particular calibration for the location procedure; the coefficients of the formula by Sibol et al. (1987) are the same used to compile CPTI04. The BW code needs an intensity attenuation relation as a function of magnitude and epicentral distance, and the log-linear attenuation model by Pasolini et al. (2008) was chosen.

The input data were the MCS scale intensities, as both the coefficients of the Sibol et al. (1987) formula and the attenuation model by Pasolini et al. (2008) are calibrated against macroseismic data in MCS scale. The code "D" attributed to nine places to account for generic damage (Section 4) was converted into $I$ 6-7 in a conservative way.

The epicentral coordinates resulting from the Boxer code are $45.424^{\circ} \mathrm{N}$ and $9.839^{\circ} \mathrm{E}$ (Fig. 9); the magnitude is $\mathrm{Mw} 6.02 \pm 0.13$ (Table 3), and the epicentral intensity is Io $8 \mathrm{MCS}$. The 


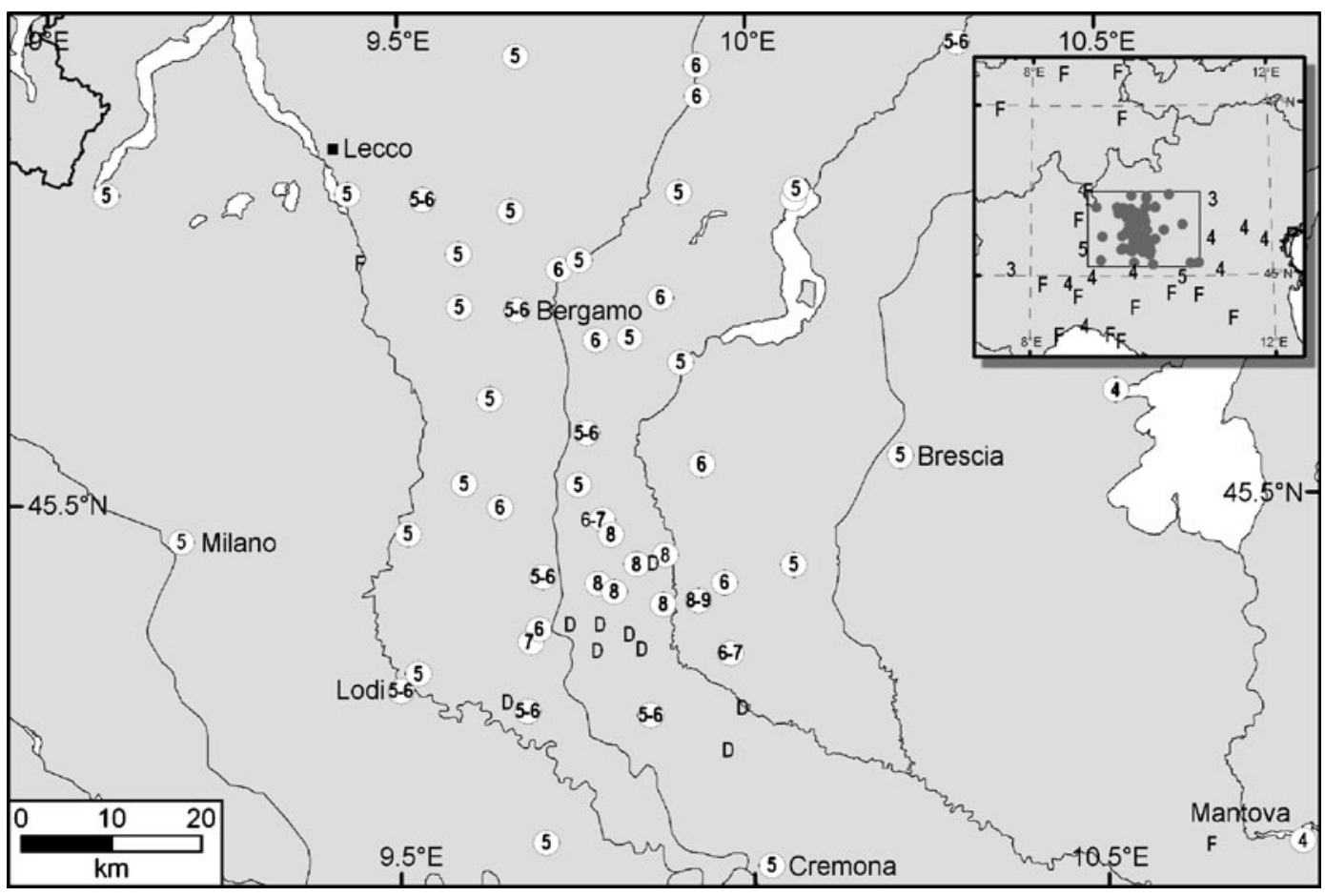

Fig. 8 Intensity distribution of the 12 May 1802 earthquake (MCS scale), according to this study (Table 2)

seismogenic box computed from the distribution of the effects has a length of $12.7 \mathrm{~km}$ and a width of $8.2 \mathrm{~km}$, and it strikes $100.0^{\circ} \pm 34.2^{\circ}$ (Fig. 9).

The BW method computed an epicenter with coordinates $45.420^{\circ} \mathrm{N}$ and $9.868^{\circ} \mathrm{E}$ (Fig. 9) and
Mw 5.68 (Table 3). The root mean square (rms) value corresponding to the $95 \%$ confidence level, based on the number of data points, is 0.111 (Bakun and Wentworth 1999). The contours of the rms values corresponding to the $95 \%, 90 \%$,
Fig. 9 New parameters of the 1802 earthquake. From Boxer (star), the seismogenic source is represented with its uncertainty in both size and azimuth. From BW (asterisk), the epicenter is represented together with its confidence contours. Intensity data and main localities for which earthquake records have not been found (dots) are shown also

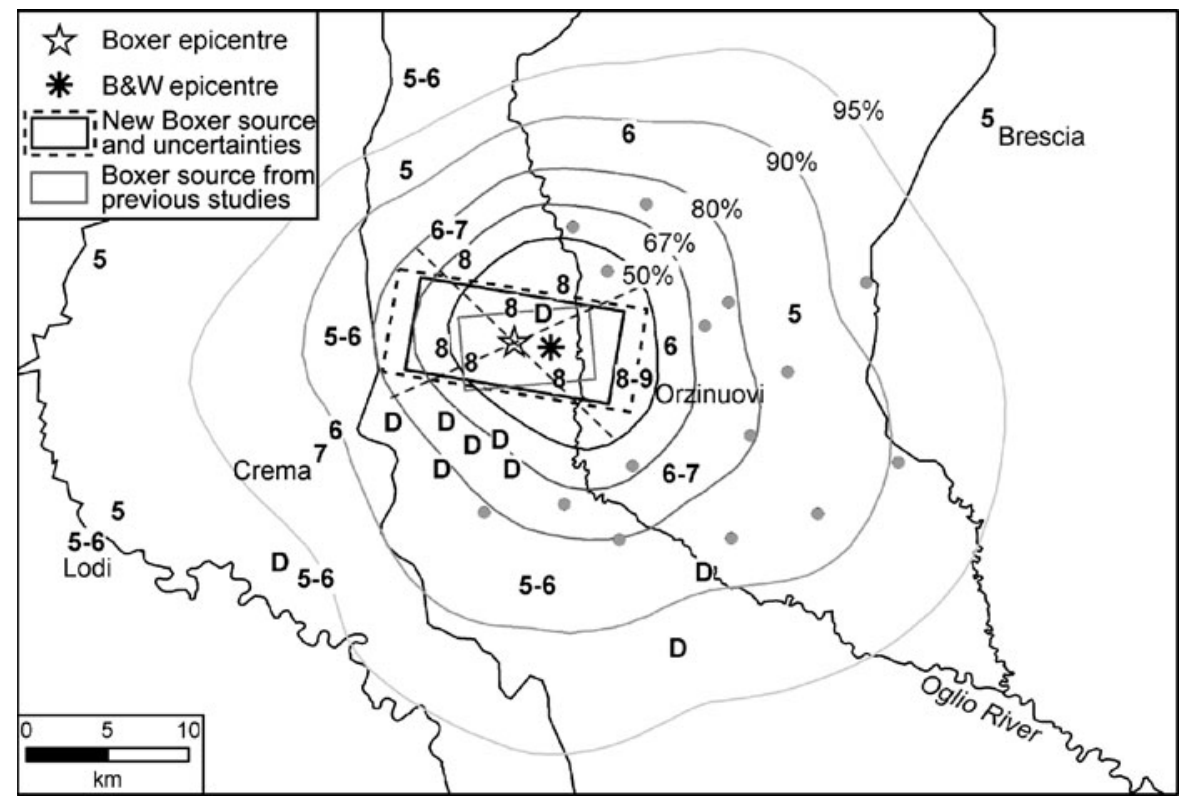


Table 3 New parameters of the 1802 earthquake, compared with those from CPTI04

\begin{tabular}{lllllllr}
\hline & Method & Lat & Lon & Mw & Box length & Box width & Box azimuth \\
\hline CPTI04 & Boxer & 45.4200 & 9.8500 & $5.67 \pm 0.09$ & 8.1 & 6.4 & $87^{\circ} \pm 43^{\circ}$ \\
This study & Boxer & 45.4242 & 9.8390 & $6.02 \pm 0.13$ & 12.7 & 8.2 & $100^{\circ} \pm 34^{\circ}$ \\
This study & B\&W & 45.4200 & 9.8680 & 5.68 & - & - & - \\
\hline
\end{tabular}

$80 \%, 67 \%$, and $50 \%$ are represented in Fig. 9; their shapes, closed around the epicenter, show that the results are sufficiently well constrained.

In order to test how the uncertainties in the intensity assessment might have influenced the parameters, three further runs of the two codes have been performed, as follows:

1. Excluding the above mentioned nine "D" datapoints, the parameters obtained do not change in both methods

2. Adopting

(a) The maximum intensity values (i.e. I 5-6 considered as 6)

(b) The minimum (i.e., I 5-6 considered as 5 ) in the case of range intensity values, the Boxer epicenters do not change, and the magnitudes slightly vary within the original uncertainty.

The epicenters obtained with the BW method are located some $2 \mathrm{~km}$ apart from the original one but are still within the original $50 \%$ confidence contour; magnitudes vary by less than 0.1 unit.

We concluded that the results provided by the two methods are sufficiently stable. Comparing them (Fig. 9; Table 3), the epicenters are just few kilometers apart, and Mw differs by 0.3 , only.

\section{Conclusions}

The knowledge of the 1802 earthquake has been improved by means of a thorough reappraisal of the observations of its effects survived to us. In terms of geographical distribution of the observations, the wealth of documents survived at the State Archive of Bergamo for the Department of Serio extended the known effects far to the north in the valleys of Bergamo. On the other hand, the investigation confirmed the consistent gaps in the survived documentation: the most significant loss concerns the surveys of the most damaged
Fig. 10 The 1802 earthquake parameters compared with the seismotectonic setting of the area

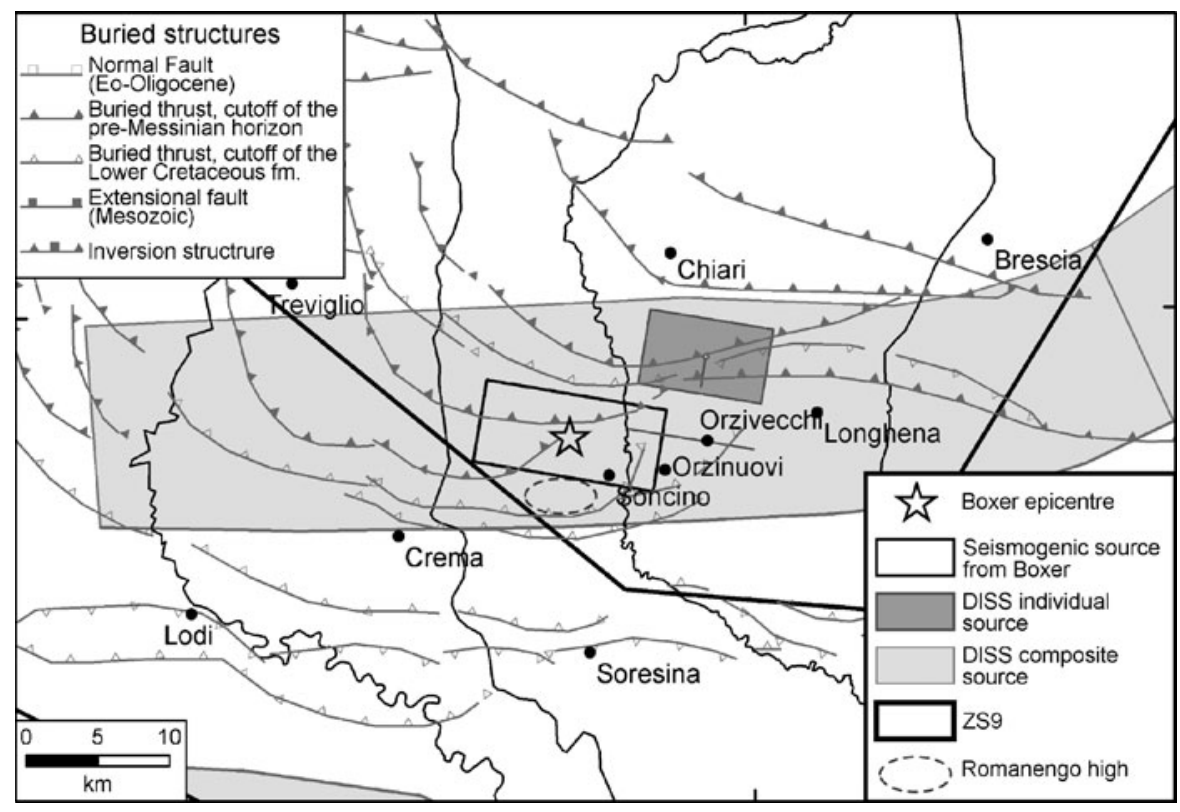


places that we know engineer Brioschi compiled and deposited a few months after the earthquake. Although the information on the damage sustained at some places remains of a poor quality, the amount of macroseismic intensity data points increased of the $30 \%$ and concerns now 94 places. Intensity values were thouroughly reassessed and made available in two different intensity scales, MCS and EMS98.

The epicentral location did not change very much with respect to that of CPTI04 (Fig. 9; Table 3). The missing data, especially in the areas to the east of Orzivecchi and to the south of Soresina, still influence the location; new data might make the epicenter move a few kilometers to the east, at most.

The Mw obtained by BW is substantially the same as in CPTI04. The Mw value assessed with the Boxer code is 6.0 and is slightly higher than in CPTI04 (5.7), due to the increased contribution of the areas with $I 6$ and 7. As a consequence, the seismogenic box obtained from the new intensity distribution is larger than the one supplied by the previous dataset, exactly by $4.5 \mathrm{~km}$ in length and 1.4 in width (Fig. 9). The azimuth of the new box is rotated $13^{\circ}$ clockwise; it now carries an uncertainty of about $32^{\circ}$, which is smaller than the one from the previous dataset $\left(43^{\circ}\right)$ but fits better the general NNW-ESE trend of the buried tectonic structures (Fig. 10).

In general, the new data offer a more stable picture of the earthquake, a picture that is compatible with the seismogenic source proposed by DISS. The offset of the most damaged area with respect to the DISS source might be partly ascribed to the lack of data in the eastern area and partly to the source directivity patterns, as it happened in many cases including the 6 April 2009, L’Aquila earthquake.

Acknowledgements Many important suggestions on the historical-seismological reconstruction were proposed and then discussed at length together with Max Stucchi: to him go our sincere thanks. We would like to thank also Paola Migliavacca and Andrea Moroni for their substantial contribution to the historical investigation this paper relies upon. The paper benefitted also from the comments by Fabrizio Galadini, Paolo Galli, and Diego Molin, as well as the remarks by two anonymous reviewers.

\section{References}

\section{Documentary sources}

ASBg (Archivio di Stato di Bergamo) (1802-1810) Prefettura del Dipartimento del Serio, Sanità, Terremoti e incendi (Earthquakes and Fires), b. 1239

ASBg (1784-1814) Prefettura del Dipartimento del Serio, Censo, b. 334, Fontanella

ASBg (1802-1809) Prefettura del Dipartimento del Serio, Censo, b. 267: Casaletto e Melotta

ASBg (1802-1815) Prefettura del Dipartimento del Serio, Polizia, b. 1077

ASBg (1802a-f) Dipartimento del Serio, Sanità, b. 1239: (a) Lettera dei Deputati di Caravaggio al Commissario di Governo del Dipartimento del Serio, 12 Maggio; (b) Annotazione senza firma da Lovere, 12 Maggio; (c) Lettera del Commissario di governo del Dipartimento del Serio al Ministro degli Affari Interni, 13 Maggio; (d) Lettera dei Deputati di Casaletto e Melotta al al Ministro degli Affari Interni, 13 Maggio; (e) Lettera della deputazione all'Estimo di Torre Pallavicina Commissario di Governo del Dipartimento del Serio, 21 Maggio; (f) Lettera della Deputazione Comunale di Fontanella al Commissario di Governo del Dipartimento del Serio, 21 Maggio

ASBg (1802g-m) Dipartimento del Serio, Sanità, b. 1239: (g) Lettera del Commissario di governo del Dipartimento dell'Alto Po al Commissario di Governo del Dipartimento del Serio, 23 Maggio; (h) Lettera del Commissario di governo del Dipartimento del Serio alla Deputazione all'Estimo di Torre Pallavicina, 24 Maggio; (i) Lettera del Commissario di governo del Dipartimento del Serio al Cancelliere di Soncino, 28 Maggio; (j) Lettera del Commissario di governo del Dipartimento del Serio alla Deputazione all'Estimo di Fontanella, 28 Maggio; (k) Lettera dei Deputati all'estimo di Casaletto e Melotta, giugno; (1) Lettera del Cancelliere censuario del distretto della Calciana al Commissario di governo del Dipartimento del Serio, 1 giugno; (m) Lettera del Cancelliere censuario del Distretto II, dipartimento del Serio, di trasmissione delle "Note dei danni... nei comuni di Casaletto e Melotta," 4 Giugno

ASBg (1802n-q) Dipartimento del Serio, Sanità, b. 1239: (n) Lettera dei Deputati all'estimo di Torre Pallavicina, senza destinatario, 10 giugno; (o) Lettera dei Deputati all'estimo di Torre Pallavicina al Commissario di governo del Dipartimento del Serio, 10 giugno; (p) Lettera del Commissario di governo del Dipartimento del Serio al Ministro degli interni, 11 giugno; (q) Lettera del Prefetto del Dipartimento del Serio al Ministro degli interni, 17 Giugno

ASBg (1802t-w) Dipartimento del Serio, Sanità, b. 1239: (t) Promemoria inviato da Torre Pallavicina, senza destinatario, 4 Agosto; (u) Lettera del Ministro degli interni al Prefetto del Dipartimento del Serio, no. 14582, 5 Agosto; (v) Lettera del Ministro degli interni al Prefetto del Dipartimento del Serio, 11 Agosto; 
(w) Lettera del Prefetto del Dipartimento del Serio al Cancelliere censuario di Fontanella, 19 Settembre

ASBg (1802aa-ab) Dipartimento del Serio, Sanità, b. 1239: (aa) Lettera del Prefetto del Dipartimento del Serio all'ingegner Brioschi, 19 Settembre; (ab) Lettera del Deputato dell'estimo di Torre Pallavicina al Prefetto del dipartimento del Serio, 23 Settembre

ASBg (1802ac-aq) Dipartimento del Serio, Sanità, b. 1239: (ac) Circolare no. 7005 del Prefetto del Dipartimento del Serio ai cancellieri censuari del Dipartimento, 11 Novembre; (ad) Lettera del Cancelliere censuario di Rivolta al Prefetto di Bergamo, 15 Novembre; (ae) Lettera del Cancelliere censuario di Treviglio al Prefetto di Bergamo, 18 Novembre; (af) Lettera del Cancelliere censuario di Castro al Prefetto di Bergamo, 18 Novembre; (ag) Lettera del Cancelliere censuario di Tagliuno al Prefetto di Bergamo, 20 Novembre; (ai) Lettera del Cancelliere censuario di Alzano Maggiore al Prefetto di Bergamo, 22 Novembre; (ah) Lettera del Cancelliere censuario di Villa d'Ogna al Prefetto di Bergamo, 20 Novembre; (aj) Lettera del Cancelliere censuario di Zogno al Prefetto di Bergamo, 24 Novembre; (ak) Lettera del Cancelliere censuario di Somasca al Prefetto di Bergamo, 25 Novembre; (al) Lettera del Vice prefetto di Breno al Prefetto di Bergamo, 26 Novembre; (am) Lettera del Cancelliere censuario di Gandino al Prefetto di Bergamo, 27 Novembre; (an) Lettera del Cancelliere censuario di Martinengo al Prefetto di Bergamo, 2 Dicembre; (ao) Lettera del Cancelliere censuario di Santo Stefano al Prefetto di Bergamo, 6 Dicembre; (ap) Lettera del Cancelliere censuario di Verdello al Prefetto di Bergamo, 9 Dicembre; (aq) Lettera del Cancelliere censuario di Ponte San Pietro al Prefetto di Bergamo, 10 Dicembre

ASBg (1802ar-av) Dipartimento del Serio, Sanità, b. 1239: (ar) Lettera degli amministratori di Cepino al Ministro degli affari interni, 10 Dicembre; (as) Lettera della deputazione di Torre Pallavicina al Cancelliere di Soncino, 19 Dicembre; (at) Lettera del Cancelliere all'estimo di Piazza al Prefetto di Bergamo, 21 Dicembre; (au) Lettera del Cancelliere Censuario del Distretto dell'Imagna al Prefetto del Dipartimento del Serio, 23 Dicembre; (av) Lettera del Cancelliere di Soncino alla prefettura del Dipartimento, 27 Dicembre

ASBg (1803a-e) Dipartimento del Serio, Sanità, b. 1239: (a) Lettera del Prefetto dell'Alto Po al Prefetto del Serio, 2 Gennaio; (b) Lettera degli amministratori di Cepino al Ministro degli affari interni, 9 marzo; (c) Lettera del Prefetto del Serio al cancelliere censuario dell'Imagna, 8 giugno; (d) Lettera del pagatore delegato in Fontanella, senza destinatario, 11 Luglio; (e) Lettera dell'amministrazione municipale di Fontanella al cancelliere del censo del distretto I del dipartimento del Serio, 13 Agosto

ASBg (1803g-i) Dipartimento del Serio, Sanità, b. 1239: (g) Lettera del cancelliere censuario di Fontanella al Prefetto del Serio, 28 Settembre; (h) Prospetto delle somme erogate, a cura del Cancelliere Censuario del
II distretto dell'Alto Po, 19 Settembre; (i) Prospetto delle somme erogate, senza firma e senza luogo, Ottobre

ASBs (Archivio di Stato di Brescia) (1797-1815) Amministrazione centrale, poi Prefettura del Dipartimento del Mella, 327 buste e 194 registri

ASBs (1783-1805) Archivio Storico Comunale di Orzinuovi, Deliberazioni del Consiglio Comunale, Orzinuovi, b. 33-34 (numero unico): binded volume, 1783-1799; 1802-1805

ASBs (1793-1815) Atti della Valcamonica, b. 143, "Terremoti e incendi"

ASBs (1802-1815) Intendenza di Finanza, 111 buste

ASBs (1802a-b) Dipartimento del Mella, b. 306: (a) Lettera della giunta municipale di Orzinuovi al Commissario di governo del Dipartimento del Mella, 12 Maggio; (b) Lettera del Commissario di Governo del Dipartimento del Mella al ministero degli Interni, 13 Maggio; (c) Relazione sulla visita fatta a Orzinuovi inviata al Ministro degli Affari Interni, 14 Maggio

ASBs (1802d-n) Dipartimento del Mella, b. 306: (d) Lettera del Ministro degli Interni al Commissario di governo del Dipartimento del Mella, 15 Maggio; (e) Lettera al Ministro degli Affari Interni, 17 Maggio; (f) Nota del capomastro di Orzinuovi, 21 Maggio; (g) Lettera del Commissario di governo del Dipartimento del Mella, 21 Maggio; (h) Elenco dei danneggiati di Orzinuovi, [Maggio]; (i) Spese sostenute per legnami e operai, 21 Maggio, (j) Elenco dei danneggiati di Orzinuovi, 21 Maggio; (k) Prospetto delle spese per la puntellatura delle case cadenti, 22 Maggio; (1) Relazione dell'architetto Donegani al Commissario di Governo del Dipartimento del Mella, 25 Maggio; (m) Considerazioni sulla relazione dell'architetto Donegani; (n) Lettera del Commissario di governo del Dipartimento del Mella, 27 Maggio

ASBs (1802o-u) Dipartimento del Mella, b. 306: (o) Lettera del ministro degli interni al commissario di governo del dipartimento del Mella, 3 giugno; (p) Lettera del Prefetto di Brescia al ministro degli affari interni, 18 giugno; (q) Lettera del ministro degli interni al Prefetto di Brescia, 5 Agosto; (r) Lettera del ministro degli interni al Prefetto del dipartimento del Mella, Brescia, 11 Agosto; (s) Lettera del Prefetto del Dipartimento del Mella alla municipalità di Orzinuovi, 13 Agosto; (t) Lettera del Ministro degli Affari interni al prefetto del Dipartimento del Mella, 13 Agosto; (u) Lettera del Prefetto del Dipartimento del Mella alla municipalità di Orzinuovi, 13 Agosto

ASBs (1802v-w) Atti della Valcamonica (1793-1815), b. 143, "Terremoti e incendi": (v) Copia della circolare 7005 inviata dal Prefetto del Dipartimento del Serio, 11 Novembre 1802; (w) Lettera del vice prefetto di Breno al Prefetto del Dipartimento del Serio, 26 Novembre 1802

ASBs (1804) Archivio Storico Comunale di Orzinuovi, Deliberazioni del Consiglio Comunale, Orzinuovi, b. 33-34: reg. 33, cc. 94 ss

ASCSoncino (Archivio Storico Comunale di Soncino) (1802) Acque e strade, b. 2.3: Carteggio relativo alle "specifiche" delle spese sostenute da diversi 
artigiani per restaurare le abitazioni di cittadini indigenti del comune di Soncino, danneggiati del terremoto verificatosi nel mese di maggio del 1802, 279 carte

ASCSoncino (1802a-c, e, g-h, k, m-n) Acque e strade, b. 2.2: Carteggio relativo al progetto per la modificazione del perimetro esterno di alcune case private, onde rendere più agevole piazza S. Martino. (a) Lettera dell'ingegner Brioschi e di alcuni cittadini, 21 Agosto; (b) Lettera del canonico Bonafini, 21 Agosto; (c) Lettera dei deputati all'Estimo, 21 Agosto; (e) Lettera dell'ingegner Brioschi alla Deputazione all'estimo, 9 Settembre; (g) Lettera di Carlo Nojetti al Cancelliere di Soncino, 24 Settembre; (h) Lettera del Cancelliere di Soncino al Prefetto dell'Alto Po, 25 Settembre; (k) Avviso della Deputazione all'Estimo ai cittadini di Soncino, 14 Ottobre; (m) Relazione dei deputati all'Estimo, 30 Ottobre; (n) Lettera di Carlo Nojetti ai Deputati all'Estimo, 4 Novembre

ASCSoncino (1802o-t) Acque e strade, b. 2.4: Corrispondenza e documentazione generale. (o) Specifica degli incassi e dei pagamenti a firma Della Volta, 10 Novembre; (q) Lettera del vice prefetto dell'Alto Po al Cancelliere di Soncino, 1 Dicembre; (r) Lettera del Cancelliere di Soncino, 5 Dicembre; (s) Lettera del Cancelliere di Soncino al Vice prefetto di Crema, 6 Dicembre; (t) Lettera dei deputati di Torre Pallavicina al Cancelliere di Soncino, 9 Dicembre

ASCSoncino (1802d, f, i-j, l, u) Acque e strade, b. 2.5: Lavori per la ristrutturazione del palazzo Pretorio, a seguito del danneggiamento del terremoto. (d) Lettera della Deputazione all'Estimo all'ingegner Brioschi, 24 Agosto; (f) Lettera dell'ingegner Brioschi alla Deputazione all'Estimo, 10 Settembre; (i) Perizia dei costi per la demolizione e ricostruzione del palazzo, 29 Settembre; (j) Valutazione dei lavori e delle spese necessarie alla costruzione del palazzo, 30 Settembre; (1) Lettera del canonico Bonafini al consiglio municipale, 30 Ottobre; (u) Lettera e mappa del palazzo Pretorio di Soncino, firmate da G. Brioschi, Milano, 21 Dicembre

ASCSoncino (1803a) Acque e strade, b. 2.4: Corrispondenza e documentazione generale. Lettera del Cancelliere di Soncino al Vice prefetto di Crema, 22 Gennaio

ASCSoncino (1803b-d) Acque e strade, b. 2.5: Lavori per la ristrutturazione del palazzo Pretorio, a seguito del danneggiamento del terremoto. (b) Lettera del prefetto dell'Alto Po sull'approvazione del progetto per il rifacimento del palazzo, 7 Febbraio; (c) Certificato delle somme assegnate dal governo per la ricostruzione del palazzo, 13 Luglio; (d) Elenco parziale delle partite di spesa, senza firma e senza destinatario, 13 Agosto

ASMi (Archivio di Stato di Milano) (1802a-d) Vicepresidenza Melzi, b. 45, Prefettura del Mella: (a) Lettera del prefetto Verri a Melzi, 21 giugno; (b) Lettera del prefetto Verri a Melzi, 6 Agosto; (c) Lettera del prefetto Verri a Melzi, 22 Ottobre; (d) Lettera del prefetto Verri a Melzi, sd

ASMi (1802-1804) Vicepresidenza Melzi - Restituito, b. 1, Memoriali
ASMi (1802e-f) Vicepresidenza Melzi, b. 28g: (e) Lettera del Ministro degli Interni al Vice Presidente della Repubblica Italiana, 7 Dicembre; (f) Relazione su "Tutela Amministrativa," 15 Novembre

ASMi (1803-1805) Vicepresidenza Melzi, b. 26, Terremoti (earthquakes)

ASMi (1805) Vicepresidenza Melzi, b. 26, Terremoti: Relazione, 12 Aprile

Decreto (1802) Decreto per lo stabilimento delle Prefetture e vice Prefetture, 6 Maggio 1802. Bollettino delle leggi della Repubblica Italiana dalla costituzione proclamata nei Comizi di Lione al 31 Dicembre 1802, Reale Stamperia, Milano

Legge (1801) Legge sulla divisione in dipartimenti, distretti e comuni del territorio della Repubblica Cisalpina, 23 fiorile anno IX (13 Maggio 1801). Raccolta delle leggi, proclami, ordini ed avvisi pubblicati in Milano, II, Milano

\section{Narrative sources (handwritten and printed)}

Anonymous (19th century) Memorie. In: Agnelli, G., 1895. I terremoti registrati nelle cronache lodigiane. Archivio storico per la città e comuni del circondario di Lodi, s II, vol 14, Lodi, pp 90-96

Arnaldi Tornieri A (1767-1822) Memorie di Vicenza. Manuscript, Gonzati, 22.10.13, Biblioteca Civica Bertoliana, Vicenza

Balis E (1802) Memorie, Per le nozze, ed Donati, C., 1859, Crema

Bianchi U (1772-1821) Osservazioni meteorologiche. Manuscript, Osservatorio Meteorologico, Parma

Biffignandi G (1796-1820) Memorie istoriche della città di Vigevano dall'anno 1796 all'anno 1820, edite ed annotate a cura del Prof. Alessandro Colombo. Viglevanum, 1912, a.6, fasc.1

Boccalletti G (19th century) Cronache ostigliesi. Manuscript, Archivio parrocchiale, Ostiglia

Bugoni GF (1801-1852) Cronaca di Piacenza. Manuscript, Biblioteca Comunale Passerini Landi, Piacenza, Pall. 124

Caparrotti C (1802) Memoria istorico-fisica del terremoto accaduto in Lombardia li 12 Maggio 1802. 51 pp, Milano

Cassinis GB (1802) Cronaca (1798-1806). Atti Società savonese di storia patria, 1929, 11, 31-237, Savona

Ceruti P (1834) Biografia soncinate. Milano, 398 pp

Churer Zeitung (1802) May, nn. 41 and 46

Fenini L (18th-19th century) Diario manoscritto. Manuscript, Biblioteca Civica Bonetta, Pavia, III.1

Gazzetta di Bologna (1802) Maggio 28, no. 44. Bologna

Gazzetta Nazionale della Liguria (1802) Maggio 15, no. 49. Genoa

Gazzetta Universale (1802a) Maggio 18, no. 40. Firenze

Gazzetta Universale (1802b) Maggio 22, no. 41. Firenze

Giovio G (1802) Lettera. Corriere del Lario, 1851, II, no. 7, 12 Febbraio, p. 26

Il Corriere Milanese (1802a) Maggio 13, no. 38. Milano

Il Corriere Milanese (1802b) Maggio 17, no. 39. Milano

Journal de Turin (1802) 26 Floreal (16 May). Torino 
Lampugnani GB (19th century) Memorie sulla vita del Conte Giovanni Antonio della Beretta, Vescovo di Lodi. Archivio storico per la città e comuni del circondario di Lodi, 1891, 97-112; 1892, 1-37, Lodi

Manini L (1819-1820) Memorie storiche della città di Cremona, 2 voll., 223 pp, 228 pp, Cremona

Massari L (18th-19th century) Memorie. Manuscript, no. 249, Biblioteca Comunale, Crema

Moniteur Universel (1802) 6 Prairial (25 May). Paris

Monti D (18th-19th century) Memorie (di Castellucchio). Manuscript, Archivio Storico Diocesano, Mantova

Morcelli SA (1780-1815) Memorie della prepositura clarense, eds Belotti I, Formenti F, Gobbi E, 2007. Ed Morcelliana, Brescia, $432 \mathrm{pp}$

Morisio G (1787-1827) Memorie di Casalmaggiore dal 1787 al 1827. Manuscript, XX-H-25, 3 voll., Biblioteca Civica, Casalmaggiore

Penada J (1808) Tavole metereologiche e necrologiche, Maggio 1802. Padova

Perini F (19th century) Delle chiese d'Orzinuovi. Monaldeschi L, Valotti C (eds), 1983, Comune di Orzinuovi-Biblioteca comunale di Orzinuovi, $302 \mathrm{pp}$

Rosa V (19th century) Memorie mie. Manuscript, X-H38/53, 16 voll., Biblioteca del Seminario Vescovile, Mantova

Rusconi PM (1802) Lettera a G. Romegialli, 18 Maggio. Manuscript, Archivio di Stato di Sondrio, Raccolta Romegialli, cart. 43, fasc. 1, lettera 6

Tommaselli G (1815) Osservazioni meteorologiche per l'anno 1802. Memorie Accademia di agricoltura, commercio e arti di Verona, 7

\section{Studies}

Albini P, Camassi R, Castelli V, Stucchi M (eds) (2001) Miglioramento delle qualità delle informazioni macrosismiche per un loro utilizzo nella valutazione della pericolosità sismica. Rapporto tecnico INGV-MI per il Servizio Sismico Nazionale, Milano, $195 \mathrm{pp}$

Bakun WH, Wentworth CM (1997) Estimating earthquake location and magnitude from seismic intensity data. Bull Seismol Soc Am 87:1502-1521

Bakun WH, Wentworth CM (1999) Erratum to estimating earthquake location and magnitude from seismic intensity data. Bull Seism Soc Am 89:557

Baratta M (1895-1897) Il terremoto sentito in Lombardia il 27 Novembre 1894. Contribuzione allo studio dell'attività sismica nell'Italia settentrionale. Atti della Società Toscana di Scienze Naturali residente in Pisa, Processi verbali, Pisa, vol. 10:41-55

Baratta M (1901) I Terremoti d'Italia. Saggio di Storia, Geografia e Bibliografia Sismica Italiana con 136 sismocartogrammi. Torino, $950 \mathrm{pp}$

Basili R, Valensise G, Vannoli P, Burrato P, Fracassi U, Mariano S, Tiberti MM, Boschi E (2008) The Database of Individual Seismogenic Sources (DISS), version 3: summarizing 20 years of research on Italy's earthquake geology. Tectonophysics 453:20-43
Boschi E, Ferrari G, Gasperini P, Guidoboni E, Smriglio G, Valensise G (eds) (1995) Catalogo dei forti terremoti in Italia dal 461 a.C. al 1980. ING-SGA, Bologna, $970 \mathrm{pp}$

Boschi E, Guidoboni E, Ferrari G, Valensise G, Gasperini $P$ (1997) Catalogo dei Forti Terremoti in Italia dal 461 a.C. al 1990. ING-SGA, Bologna, 644 pp

Boschi E, Guidoboni E, Ferrari G, Mariotti D, Valensise G, Gasperini P (eds) (2000) Catalogue of Strong Italian Earthquakes from 461 B.C. to 1980. Ann Geofis 43:609-868

Brega F, Stucchi M, Bassi G, De Martin M (1985) The Soncino earthquake of May 12, 1802, In: Atlas of Isoseismal Maps of Italian Earthquakes, ed Postpischl D, CNR-PFG, Quaderni de "La Ricerca Scientifica," no. 114, vol 2A, Roma, pp 72-73

Burrato P, Ciucci F, Valensise G (2003) An inventory of river anomalies in the Po Plain, Northern Italy: evidence for active blind thrust faulting. Ann Geophys 46:865-882

Cassano E, Anelli L, Fichera R, Cappelli V (1986) Pianura Padana. Interpretazione integrata di dati geofisici e geologici. Proc. $73^{\circ}$ Meeting Società Geologica Italiana, Rome, 29 September-4 October 1986, 27 pp

Castellarin A, Cantelli L, Fesce AM, Mercier JL, Picotti V, Pini GA, Prosser G, Selli L (1992) Alpine compressional tectonics in the Southern Alps: relationships with the Apennines. Annales Tectonicae 6:62-94

Castello B, Selvaggi G, Chiarabba C, Amato A (2006) CSI Catalogo della sismicità italiana 1981-2002, versione 1.1. INGV-CNT, Rome. http://www.ingv.it/CSI/. Accessed 15 October 2009

CPTI04 Working Group (2004) Catalogo Parametrico dei Terremoti Italiani, versione 2004 (CPTI04), INGV, Bologna. http://emidius.mi.ingv.it/CPTI04/. Accessed 15 October 2009

Cremona (2000) Le istituzioni storiche del territorio lombardo $14^{\circ}-19^{\circ}$ secolo. Progetto Civita, Regione Lombardia, Milano, 397 pp

Desio A (1965) I rilievi isolati della Pianura Lombarda ed i movimenti tettonici del Quaternario. Rend Ist Lom Acc Sc Lett, Sez A 99:881-894

ENEL (1986) Il terremoto del 3 Gennaio 1117. Studi ed indagini per l'accertamento della idoneità tecnica delle aree suscettibili di insediamento di impianti nucleari, Regione Lombardia, Area Viadana, indagini di sismicità storica. Rapporto finale, ISMES-RAT-DGF0012, 907 pp

Fantoni R, Bersezio R, Forcella F (2004) Alpine structure and deformation chronology at the southern AlpsPo Plain border in Lombardy. Boll Soc Geol It 123: 463-476

Galadini F, Galli P, Molin D, Ciurletti G (2001) Searching for the source of the 1117 earthquake in northern Italy: a multidisciplinary approach. In: Glade T, Albini $\mathrm{P}$, Frances F (eds) The use of historical data in natural hazard assessments. Kluwer Academic Publisher, pp 3-27

Galantino F (1869) Storia di Soncino con documenti. Milano, 3 voll., 401 pp, 453 pp, 525 pp 
Galli P (2005) I terremoti del Gennaio 1117. Ipotesi di un epicentro nel Cremonese. Il Quaternario 18:85-100

Gasperini P, Bernardini F, Valensise G, Boschi E (1999) Defining seismogenic sources from historical earthquake felt reports. Bull Seismol Soc Am 89: 94-110

Grandi A (1856) Descrizione dello stato fisico-politicostatistico-storico-biografico della provincia e diocesi di Cremona, Cremona, $754 \mathrm{pp}$

Gruenthal G. (1998) (ed) European Macroseismic Scale 1998. Cahiers du Centre Europèen de Gèodynamique et de Seismologie. Conseil de l'Europe

Guidoboni E (1984) 3 Janvier 1117: le tremblement de terre du Moyen Age roman. Aspects des sources. In: Helly B, Pollino A (eds) Tremblements de terre, histoire et archéologie, IVèmes rencontres internationales d'archéologie et histoire d'Antibe, Actes du colloque, 2-4 Novembre 1983 CNRS, Valbonne, pp 11-39

Guidoboni E, Boschi E (1989) I grandi terremoti medievali in Italia. Le Scienze 249:22-35

Guidoboni E, Comastri A (2005) Catalogue of earthquakes and tsunamis in the Mediterranean area from the 11th to the 15th century. INGV-SGA, Bologna, $1037 \mathrm{pp}$

Guidoboni E, Comastri A, Boschi E (2005) The "exceptional" earthquake of 3 January 1117 in Verona area (northern Italy): a critical time review and detection of two lost earthquakes (Lower Germany and Tuscany). J Geophys Res 110:B12309

Guidoboni E, Ferrari G, Mariotti D, Comastri A, Tarabusi G, Valensise G (2007) CFTI4Med, Catalogue of Strong Earthquakes in Italy (461 B.C.-1997) and Mediterranean Area (760 B.C.-1500). INGV-SGA, http://storing.ingv.it/cfti4med/. Accessed 15 October 2009

INGV Monthly Bulletin (2003-2008) http://legacy.ingv. it/ roma/reti/rms/bollettino/index.php. Accessed 15 October 2009

Jiménez MJ, Giardini D, Gruenthal G, SESAME Working Group (2001) Unified seismic hazard modelling throughout the Mediterranean region. Boll Geofis Teor Appl 42:3-18

Magri G, Molin D (1986) I terremoti del 3 Gennaio 1117 e del 25 Dicembre 1222. Rapporto ENEA, RTI-PASISP-GEOL LO (86)2, 9 pp

Marchetti M (1990) Cambiamenti idrologici nella Pianura Padana centrale a Nord del Fiume Po: i casi di "underfit streams" dei fiumi Mincio, Oglio e Adda. Geogr Fis Din Quat 13:53-62

Meletti C, Galadini F, Valensise G, Stucchi M, Basili R, Barba S, Vannucci G, Boschi E (2008) A seismic source zone model for the seismic hazard assessment of the Italian territory. Tectonophysics 450:85-108

Meletti C, Patacca E, Scandone P (2000) Construction of a seismotectonic model: the case of Italy. Pure and Appl Geophys 157:11-35

Mercalli G (1883) Vulcani e fenomeni vulcanici in Italia. Milano $374 \mathrm{pp}$
Mercalli G (1897) I terremoti della Liguria e del Piemonte. Napoli, 146 pp

MPS Working Group (2004) Redazione della mappa di pericolosità sismica prevista dall'Ordinanza PCM 3274 del 20 marzo 2003. Rapporto Conclusivo per il Dipartimento della Protezione Civile, INGV, Milano-Roma, 2004 april. 65 pp +5 appendixes. http://zonesismiche.mi.ingv.it. Accessed 15 October 2009

Musson RMW, Gruenthal G, Stucchi M (2010) The comparison of macroseismic intensity scales. J Seismol. 14(2):413-428. doi:10.1007/s10950-009-9172-0

Pasolini C, Albarello D, Gasperini P, D'Amico V, Lolli B (2008) The attenuation of seismic intensity in Italy: part ii: modeling and validation. Bull Seismol Soc Am 98:692-708

Pieri M, Groppi G (1981) Subsurface geological structure of the Po Plain (Italy). Publ. no. 414, Progetto Finalizzato Geodinamica, C.N.R., Rome, 23 pp

Pondrelli S, Morelli A, Ekström G (2004) EuropeanMediterranean Regional Centroid Moment Tensor catalogue: solutions for years 2001 and 2002. Phys Earth Planet In 145:127-147

Pondrelli S, Salimbeni S, Morelli A, Ekström G, Boschi E (2007) European Mediterranean Regional Centroid Moment Tensor catalog: Solutions for years 2003 and 2004. Phys Earth Planet In 164:90-112

Postpischl D (1985) Catalogo dei terremoti italiani dall'anno 1000 al 1980, Quaderni della Ricerca Scientifica, 114, 2B, Bologna, 239 pp

Sforza Benvenuti F (1859) Storia di Crema. Milano , 2 voll., $412 \mathrm{pp}, 431 \mathrm{pp}$

Sibol MS, Bollinger GA, Birch JB (1987) Estimations of magnitudes in central and eastern North America using intensity and felt aRea. Bull Seismol Soc Am $77: 1635-1654$

Sieberg A (1930) Geologie der Erdbeben. Handbuch der Geophysik 2(4):550-555

Stucchi M, Albini P, Mirto C, Rebez A (2004) Assessing the completeness of Italian historical earthquake data. Ann Geophys 47(2-3):659-673

Stucchi M, Camassi R, Rovida A, Locati M, Ercolani E, Meletti C, Migliavacca P, Bernardini F, Azzaro R (eds) (2007) DBMI04, il database delle osservazioni macrosismiche dei terremoti italiani utilizzate per la compilazione del catalogo parametrico CPTI04. http://emidius.mi.ingv.it/DBMI04/. INGV, Quaderni di Geofisica 49, 38 pp. Accessed 15 October 2009

Stucchi M, Galadini F, Rovida A, Moroni A, Albini P, Mirto C, Migliavacca P (2008) Historical investigation of earthquakes before 1700 between the Adda and the lower Adige river basins (Southern Alps). In: Fréchet J, Meghraoui M, Stucchi M (eds) Historical seismology. Springer, pp 209-230

Wells DL, Coppersmith KJ (1994) New empirical relationships among magnitude, rapture length, rupture width, rupture area, and surface displacement. Bull Seismol Soc Am 84:974-1002 